\title{
The Spillovers of Competition: Value-based Activism and Political Cross-fertilization in an Indian Campus
}

Jean-Thomas Martelli

\section{OpenEdition}

\section{Journals}

Electronic version

URL: http://journals.openedition.org/samaj/6501

DOI: 10.4000/samaj.6501

ISSN: 1960-6060

Publisher

Association pour la recherche sur l'Asie du Sud (ARAS)

\section{Electronic reference}

Jean-Thomas Martelli, «The Spillovers of Competition: Value-based Activism and Political Crossfertilization in an Indian Campus », South Asia Multidisciplinary Academic Journal [Online], 22 | 2019 Online since 01 January 2020, connection on 10 July 2020. URL : http://journals.openedition.org/ samaj/6501 ; DOl : https://doi.org/10.4000/samaj.6501

This text was automatically generated on 10 July 2020 .

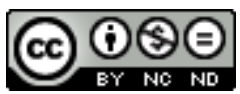

This work is licensed under a Creative Commons Attribution-NonCommercial-NoDerivatives 4.0 International License. 


\title{
The Spillovers of Competition: Value-based Activism and Political Cross-fertilization in an Indian Campus
}

\author{
Jean-Thomas Martelli
}

1 Situated at the crossroads of various biographical and historical dynamics, contemporary student activism in Indian universities is either idealized as a vessel for grievance-based countercultural politics (Henry 2018; Pathania 2018; Poonam 2018) or trivialized as a platform for the accumulation or the reproduction of wider dominant sociopolitical realities (Jeffrey 2010) based on caste (Kumar 2012; Young, Kumar and Jeffery 2016) or gender (Lukose 2009). ${ }^{1}$ Student activism in the Indian context is understood variously as a service lane of wider politics (Hazary 1987), as a platform strengthening existing social stratifications (Jeffrey 2008), or as a reified cultural artefact (Pathania 2018). By not accounting for specific campus socio-political dynamics, such perspectives overlook the processes by which select residential universities become prolific spaces of political socialization. Such mechanisms are critical in enabling sections of educated youth to reinterpret existing political narratives. Because they under-report the grounded micro-processes that fuel the distinctiveness of shared political spaces, existing approaches are ill-equipped to identify the specific transmission of political understandings in Indian campuses when compared to other social spaces.

2 This article examines the role of campus spaces in the gradual politicization of associational ties among students. It explores the conditions by which the social arrangements of campus spaces favor the emergence of dissenting forms of political participation. I understand dissent here as the ability to mount symbolic political challenges through communicating the message of difference to the rest of society (Melucci 1996). Following Klandermans (1997), I define participation in political life as the affective, normative, ideational and diachronic aspects of one's involvements in 
collective action, which entails the networks, psychological engagements and resources that sustain them (Brady et al. 1995). Political participation in JNU is operationalized through observing the frequency of student attendance in political events as well as the self-declared affiliations of students to political groups on campus (Martelli and Ari 2018). In the ambit of the study, I use the term politicization as the process of "gradual transformation of political attitudes in light of prolonged exposure to a campus environment" (Martelli and Ari 2018:263). Here politicization of daily student life is understood as the sequence of politicizing events that gradually restructure the understanding individuals have of the society in which they thrive (Stekelenburg 2013).

By engaging with the case of student politics at a flagship postgraduate and residential pan-Indian university, Jawaharlal Nehru University (JNU), I argue that competitive party politics drives inter-cohort political socialization in residential campuses while nurturing political spillovers, defined as the diffusion mechanisms and spinoff processes accounting for the emergence of new cycles of protest, mobilization and political awareness (McAdam 1995). Through fostering a participatory community culture based on the circulation of collective practices among politically socialized micro-cohorts (Whittier 1997), the competition between student organizations at JNU provides special impetus for critiques going beyond party-lines by nurturing ideological cross-fertilization. While organized political competition, facilitated by the on-campus concentration of students free from many social constraints (Hirsch 1990) enables the circulation of political capital among student batches, I show that dissension increases in such politicization as processes of ideological cross-fertilization emerge. Overall, political spillovers are likely to produce dissent because they create multiple discursive perspectives, contribute to the sustenance of transformative groupbased political experiences, and ultimately strengthen distinctive political identifications and worldviews on campus.

4 The empirical analysis shows that these spillovers lead to the emergence of counterdiscourses in addition to generating mutual political influence (Meyer and Whittier 1994). I suggest that dissonant claims in a sociologically diverse campus such as JNU (Martelli and Parkar 2018) are better understood as the byproduct of political competition rather than the result of the oppression of dominant groups (Scott 1990) outside and inside campus.

5 The manuscript combines archival methods and an ethnography of JNU from 2014 till date. The ethnographic insight builds on participant observation, semi-structured faceto-face interviews with former and current JNU student activists, professors, and "common students." My preliminary insights are based on sixteen months of fieldwork at JNU (February 2014-May 2015) in which I lived in a shared hostel room on campus, attended classes and political events, stayed with activists and travelled with them in their numerous political campaigns both in Delhi and outside the capital. The fieldwork was complemented by four short visits to Delhi in March 2016 and December 2018. A new round of interviews was conducted in 2019 as part of an exhibition project on the legacies of campus politics in India in which most respondents' interviews were filmed or recorded as well as transcribed.

6 As part of my ethnographic work, I progressively collected pamphleteer material (pamphlets, posters, manifestos, reports, press releases, letters to administration, statements, posters, wall paintings, murals, songs, slogans) from various JNU student organizations and individuals who had kept personal records of their activist years. 
The 73,782 documents, covering the period 1973-2019, were subsequently digitized, OCRized (text was extracted) and archived on a new freely accessible online platform, the "Pamphlet Repository for Changing Activism" (PaRChA) (2019).

7 The choice of JNU as a case study has several advantages. Less prone to engaging in interest-based and muscle politics, its strand of student politics displays strong signs of ideological forms of activism. Such propensity makes JNU a most-likely case to observe the mechanisms of ideational political spillovers occurring in campus premises. JNU, a public-funded residential central university is admittedly different from other Indian institutions for higher education in several respects: it is postgraduate oriented, English-medium and perceived as a prestigious social science institution located in the capital city. On the other hand, however, the administrative functioning of the university as well as residential nature of campus student politics is generalizable to other social-science public institutions in the country. The longstanding tradition of affirmative action in JNU as well as its pan-India scope makes the university truly representative of the sociological fabric of the country. Additionally, the variety of student political groups active on the JNU campus embraces broad sections of the rich ideological spectrum permeating politics. In those respects, JNU can be seen as a 'miniIndia'. Last but not least, because the current government pronounced the university as a den of anti-national dissenters, it has turned the campus into the all-encompassing symbol of value-based student political participation in India.

8 I divide the rest of the article into two distinct sections. First, I discuss the relevance of the study of political spillovers to the understanding of political movements and student politics in South Asia. After drawing the contours of student competition at JNU, I empirically elucidate the mechanisms that activate and maintain political socialization on campus. I argue that the political character of JNU is fashioned by the on-campus rivalry between student outfits of political parties, including left, Dalit and Hindutva groups, whose competitiveness engenders discourses relying on outbidding tactics while simultaneously fueling ideological cross-fertilization among affiliated and non-affiliated student groups.

\section{Locating the Distinctiveness of Politics in Campus Spaces}

9 In this section I examine the conditions under which it is possible to consider campuses as sites conducive to the emergence of distinctive political capital. Through a discussion on the centrality of political competition and its nonviolent outbidding logic, I mobilize the concept of political spillover to make sense of the manner in which intra-campus political rivalry paves the way for the formation of identifiable political idioms. The outbidding logic indicates strong advocacy in the name of a more genuine political line rooted in the interests of a political group (Bajpai and Farooqui 2018:293) supporting the demise of ideological moderation (Rabushka and Shepsle 1972:117). The subsequently produced spillovers are understood as the diffusion from one group to another of a range of political characteristics including ideas, frames, collective identities and cultures of mobilization (Meyer and Whittier 1994:278).

While many explorations of student life focus on the socio-political stratification and merit-making on campuses across the country, ${ }^{2}$ contemporary student movements emerging from Indian universities are receiving increased academic attention (Martelli 
and Garalyte, this issue). While the content and rationale of political initiatives vary greatly across campus spaces, the identity-based as well as value-based leanings of these movements shatter previous understandings of student politics in India. Indeed, they suggest that campuses are relevant sites for the production of political idioms.

However seemingly commonsensical, this claim departs from the body of scholarship on Indian and South Asian student politics. Indeed, the first approach to "student unrest" in India, emerging in the late 1960s and pioneered by Philip Altbach (1968a; 1968b; 1970), tended to focus on the "non-political" dimension of youth participation, that is the non-ideological- material-and career aspirations of student political participants. The overall emphasis was on student insubordination to parental rules (Rege 1971; Sinha and Gangrade 1971; Singhvi 1972; Malik and Marquette 1974; Shils 1974). Until the 1980s, they pictured agitated students as being in conflict with older generations (Cormack 1961; Gusfield 1970; Di Bona 1966; Singh 1968; Ross 1969; Vidyarthi 1976), constituting an undisciplined demand group (Kabir 1958; Banerjee 1980, 1984; Rudolph and Rudolph 1987), focusing on material and administrative grievances (Altbach 1969, 1970a, 1970b; Vidyarthi 1976; Chopra 1978), turning their back on their highly nationalist pre-independence peers (Chandra 1938; Reddy 1947; Hazary 1987; Rajimwale 2001) and acting as a spring board for prospective leadership (Hazary 1987; Singh 1974; John 1969). As noted by Karnena (2019), "student indiscipline" was the hegemonic framework to understand student politics in India.

Disengaging with the view of youth as turbulent unfinished adults, a new stream of studies progressively concentrated on youth as cohorts engaging creatively with the socio-political norms surrounding them (Nisbett 2007). They approached Indian campuses as a space where exogenous social dynamics crystallize, whether this is consumerism (Lukose 2009), semi-permanent limbo (Jeffrey 2010), economic despair (Poonam 2018), pre-marital sexual conduct (Osella and Osella 1998), party politics (Hazary 1987) or the consolidation of primary socializations- that is the effects of attitudes inherited during childhood as a result of parental upbringing (Kumar 2014; Kumar 2017).

In addition to this, recent scholarship continues to depict student politics in South Asia as an articulation of interest-based politics, dealing mostly with campus accommodation, administrative efficiency, job prospects, daily amenities and castebased leadership-making (Shah 2004; Kumar 2012; Kumar 2014). Jeffrey and colleagues account for cultures of waiting among middle-class educated men (predominantly Jats) in India's Western Uttar Pradesh, showing how they reproduce their dominance at the local level, mainly through using campus politics to channel contracts for businessmen and seats for students in private local universities (Jeffrey 2008, 2010; Jeffrey, Jeffery and Jeffery 2008; Jeffrey and Young 2012; Jeffrey and Young 2013 Young, Kumar and Jeffrey 2016; Jeffrey and Dyson 2016). Similarly, in Bangladesh the focus is put on the way student organizations gain power through Bangladeshi-specific muscle-politics (Suykens and Islam 2013; Suykens 2016, 2017; Jackman 2018; Suykens 2018) and resource allocation such as on-campus accommodation distribution (Rozario 2001; Ruud 2010; Christiansen 2012; Suykens and Islam 2013; Andersen 2014; Ruud 2014; Andersen 2016). Student politics appears there as an extension of party politics, additionally building on caste-based economic capital or middle-class masculinities (Lukose 2009). 
14 Against the grain of such perspectives, which places student agency (Klemenčič 2015) into the tightening noose of pragmatic politics-as-usual, recent evidence indicates a revival of prefigurative value- and identity-based forms of student activism in South Asia. While acknowledging that student activism serves as an instrument of power assertion in South Asia, these studies unearth alternative processes of political selfformation. Snellinger (2018a) discusses sacrificial tropes among young revolutionary Maoists in $\mathrm{Nepal}^{3}$, tracing the journey of their political ideology. She portrays youth who had to renegotiate the moral idioms of their student activist years in the context of a post-civil war peace process characterized by patronage and the need to build career-based networks. Similarly, Pathania (2018) describes how student participation contributes to wider regional political regeneration. Through compiling existing accounts (Gundimeda 2009; Natrajan 2011, 2018; Garalytè 2015) he provides a picture on how several generations of Dalit-led cultural politics in Osmania University crucially contributed to the long-running mobilization for the creation of the Indian state of Telangana. From this it emerges that the mobilization of Indian youth is indispensable when rallying around identity-based issues. This includes demands to end anti-Dalit atrocities (Teltumbde 2017; Pai 2018) in Una (Gujarat) or Saharanpur (Uttar Pradesh), the inclusion of communities (such as the Patels in Gujarat) in affirmative-action quotas (Mitra 2017) or the assertion of regional identities through building on linguistic (Subramanian 1999) and ethnic claims (Baruah 1999; Deka 2015).

15 These are clear indications that universities matter politically. As exemplified by the youth-centric turmoil that surrounded the suicide of the doctoral student and Dalit activist Rohith Vemula at the University of Hyderabad in 2016 (Henry 2018), the campus appears to be a potentially conducive space for the crafting of alternative political discourses. By way of pointing out the importance of Aligarh Muslim University (Uttar Pradesh) in the emergence of the militant Students' Islamic Movement of India (SIMI), Ahmad (2009) shows not only the centrality of the university in the formation of the political identity of Muslims in India, but also highlights the possibility of contentious voices emerging within that campus space (Gautier 2018; Gautier, this issue). In Pakistan too, key university spaces (i.e. Punjab University, University of Peshawar) seem to emerge as instrumental territories for the development of new trans-nationalist political ideas about Islam (Nelson 2011). Certain campus spaces also appear instrumental in reshaping online and offline gender-based political identities: demanding safety (Dey 2018), challenging moral policing surrounding the public disclosure of romance and loitering (Kapur 2012; Murali 2016; Savory Fuller 2018) and empowering women to reclaim freedom of movement and access to public spaces at any time-for example by challenging a hostel curfew (Roy 2016) or accessing male-dominated tea shops (Poonam 2018). The sporadic emergence of young queer collectives in dialogue with several Women Studies Centers has enabled select campuses of prestigious Indian educational institutions to become platforms for the inceptive politicization of alternative sexualities (Dutoya 2016).

While acknowledging the importance of campuses in the local production of modalities of political representation, these recent works do not address the particular processes by which political idioms are generated in campus spaces. Pathania (2018) for instance argues that at Osmania University in Hyderabad, a "culture of resistance was created by intellectuals (students, alumni and teachers)," but engages neither with why "intellectuals" joined Osmania University nor on the processes by which certain 
student activists became "intellectuals" within the campus. Others (Henry 2018; Poonam 2018) do not grapple with the micro-processes of political socialization, understood here as the gradual process through which political knowledge is acquired and negotiated, leading to the development of idiosyncratic views of the political world (Wong and Tseng 2008; Fillieule 2013).

Engaging with such concerns, a recent account (Martelli and Baris 2018) indicates that exposure to campus gradually transforms the political attitudes of students at Jawaharlal Nehru University. The ethnographic part of the study argues that such political transformations are driven by an intergenerational process of peer-to peer socialization, in which politicized senior students progressively influence the attitude of younger cohorts. Value-based politicization is made possible because politically active seniors associated with student organizations maintain prolonged daily interactions with the student body through channeling and mediating student grievances. The study concludes that "sustained activist competition and rivalry, channeled by well-organized student organizations, create multiple incentives for progressive partisan identification"(Martelli and Parkar 2018:264) Further evidence (Martelli and Parkar 2018) demonstrates that such student politicization at JNU is pervasive and not structured around traditional caste divides, even though women and upper-class students tend to be less affected by it. Martelli (2019) also argues that in the context of rivalry between various affiliated political groups, the advertising of one's self-transformation enables activists to claim successful representation of sociologically diverse student communities.

18 As evidenced by several studies, group-level socialization can enable in situ political polarization, shared experiences and collective consciousness-raising among students (Hirsch 1990; Fantasia and Hirsch 1995; Leach and Haunss 2008). Campuses are ecologically useful for recruitment and mobilization because students live together and enjoy free time (Zhao 1998; van Dyke 1998; Enriquez 2014; Earl, Maher and Elliott 2017). This resonates with the literature on "safe spaces" (Gamson 1996; Hill-Collins 2000), "free spaces" (Evans and Boyte 1992; Couto 1993; Groch 2001; Futrell and Simi 2004; Johnston and Noakes 2005), "movement halfway houses" (Morris 1986; Rupp and Taylor 1987), "cultures of solidarity" (Fantasia 1988), "cultural laboratories" (Mueller 1994), "cultural havens" (Hirsch 1990; Fantasia and Hirsch 1995),"submerged networks" (Melucci 1989; Mueller 1994), "abeyance structures” (Taylor 1989; Taylor and Rupp 1993; Taylor and Crossley 2013), "oppositional subcultures” (Johnston 1991) and "social movement communities" (Buechler 1990; Taylor and Whittier 1992; Taylor and Rupp 1993; Taylor and Whittier 1995). While I do not assume the political separateness of the campus from the broader social fabric, I use this literature to examine empirically the localized metamorphosis of existing ideologies circulating in South Asia, shaped by the competition of campus-specific political outfits connected with the broader Indian party system.

19 In order to understand what drives everyday intergenerational political change in campus spaces I mobilize the concept of political spillover, i.e. the effects and influences of political movements-big or small-on each other (Giugni 2013). More specifically, I examine how attempts by rival student groups affiliated with broader political outfits to outbid each other (Mitchell, Evans and O'Leary 2009; Bajpai and Farooqui 2018) enable the "spinning off" of political initiatives, drawing critical impetus from original initiator movements (McAdam 1995). I suggest that a necessary 
condition for the emergence of political spillovers is the micro-processes that are set in motion by dense activist networks at work on campus on a daily basis.

The term spillover emerges from the social movement literature (Chabot and Duyvendak 2002; Bunce et Wolchik 2006). Engagements with the concept attempt to map the relationship between various political initiatives that belong to broader movement families (Tilly 1983) or develop in relatively coherent political scenes (Learch and Haunss 2008). Meyer and Whittier (1994) indicate that in order for spillovers to exist, a physical overlap between activist communities needs to be in place, facilitating the sharing of personnel, tactics and ideological idioms. The preexistence of shared participatory cultures and common gathering spaces are important elements of the environments through which political spillovers emanate (Whittier 2013). More specifically, those particular geographies enable the institutionalization of cultural frames allowing for ideological and network intersections (Polletta 1999; 2004).

21 After briefly presenting student politics at JNU, I introduce debates around gender issues in order to trace the emergence of political spillovers within the campus space. The process by which political spillovers disseminate on campus is further examined through a discussion of political outbidding as well as ideological cross-fertilization among affiliated and non-affiliated student groups. By examining how streams of left, Dalit, Hindutva and environmentalist discourses interbreed as a result of political competition, I make sense of how such student politics at JNU becomes distinctive, dissonant and dissenting.

\section{Dissonant Activism and Political Spillovers at the JNU}

\section{Campus Historical Background: Student Politics at JNU, from Resonant to Dissonant}

JNU arguably occupies a particular space in both the academic and political landscape. Just a few years after JNU was established at the end of the 1960s, students at this residential ${ }^{4}$ postgraduate centrally funded university- mostly in the social sciences and humanities- started electing candidates displaying Marxist leanings thus becoming, in the collective opinion, a bastion of the student left along with a few other campuses such as Jadavpur University, Presidency University (West Bengal), Osmania University (Telangana) and several colleges in Kerala (Aikara 1977). Most commentators, whether enthusiasts or skeptics, consider JNU from its inception as a landmark in youth politics in India (Batabyal 2015). It has been recognized as a socialist bastion (Pattnaik 1982), a space of academic and political dissent through debate and discussion (Shakil 2004), a place where professors preach new-left ideologies (Bhasin 1974; Suroor 2011) and an environment in which activism is an integral part of student life (Lochan 1996).

This routinely politicized university became a symbol of free speech in 2016 after the police arrested several student activists on the grounds of sedition, triggering massscale protests while deeply impacting the media discourse (Sharma 2016; Thapar 2016; Deshpande 2016; Chatterjee 2016). The pro-Hindu nationalist nexus on campus-in tune with the government at the center-instituted fines for critical teachers, prevented political activities of leftist unions, established a school for Sanskrit studies, installed a 
not-yet-inaugurated statue of Hindutva icon Swami Vivekananda, and opened a school of management which bears the name of a former BJP prime minister, Atal Bihari Vajpayee (Kidwai 2017; Paranjape 2017; Ghosh 2018; Sundar 2018; Beliappa 2018).

As a result of its largely "anti-right" political credentials, the University was severely penalized by the government of Prime Minister Narendra Modi. As a research university with a majority of Master's and MPhil-PhD degrees, JNU saw the number of seats offered to students wishing to enter the Master's or PhD program drop by $84 \%$ in 2017, from 1,234 to 194 (Chaudhry 2017; Shankar 2017). The JNU Teachers' Association (JNUTA) claimed that selection committees were de facto decided by the ViceChancellor (VC), more notably after he revised academic rules in order to unilaterally add names to the panel of experts in charge of faculty recruitment (Regulation M-18, Resol. No.6.11/EC/18.09.2017). However, a recent High Court order ruled that the VC's suggested names must be first recommended by the Academic Council compelling the JNU administration to abide by its earlier procedure (The Hindu May 17, 2019). Further control by the administration was achieved through nominating school deans and chairpersons without respecting customary seniority principles (JNUTA, October 1, 2017). Along with the VC they do have voting rights for the recruitment of faculty members, and they nominate other similar-minded voters, including a visitor and an observer from the SC/ST community (Chetan, interview 2019, The Indian Express June $25,2018)$. Because of the lack of Hindutva-compatible professors, the VC also attempted to appoint as Chairperson of a center a faculty member from another center, but that decision was later reversed in court (NDTV July 30, 2019).

As Jayal (2019) suggests, since very few academically minded faculty candidates have an ideologically compatible profile, recruitment panels tend to compromise with professional credentials. As a result, and in order to accelerate the political denaturing of JNU, the administration proceeded to recruit pro-Hindutva teachers (Shankar 2018) and academically under-qualified academics-sometimes even plagiarizers (Mahaprashasta 2018; Dasgupta 2018). It also stopped enforcing the rules that JNU had set for diversity in student admission which combined reservation quotas and deprivation points based on geographical backwardness and gender (Vishnu 2017). The new recruitment procedure is strongly disadvantageous to Dalits, Adivasi and Other Backward Classes (OBCs) who have represented almost $50 \%$ of entrants in the past and numbered only 7\% in 2018 (Nagarajan 2017). The Vice Chancellor also decided to freeze academic advancement and promotions, a decision that pushed some victims to bring the case to court (Kidwai 2018). All in all, the academic and political life at JNU is marked by systematic administrative obstruction, and going to court has become the norm in many administrative matters, including for the declaration of Jawaharlal Nehru Students' Union (JNUSU) election results (Hindustan Times, September 7, 2019).

While the political history of student activism at JNU and the threats it faces have evolved from year to year, distinct phases of political participation emerge since the university's inceptive's years (Martelli 2018). As the following phases demonstrate, JNU Students' Union has been an "object of desire" of various political organizations, as their parties see the university as a valuable space for recruiting ideologically sound youth and organize campaigns in the capital. Batabyal (2015) suggests that JNU's establishment first reflected the ambitions of center-left socialists (1964-1975). In 1971, a generation of highly educated upper-class students created a politicized Students' Union, deeply influenced by Marxist thought. This Union took an active part in the 
affairs of the University from the beginning of JNU student politics (Martelli 2018). After the Emergency, the Union and the political narrative it professed reflected more clearly the regional domination of the Communist Party of India (Marxist)-CPI(M)-in power in Kerala and West Bengal (1977-2004). In the 2000s however, the Union shifted allegiance to the Communist Party of India (Marxist-Leninist)-CPI(ML)-a former Naxalite Bihari-centric organization converted to parliamentarism (2005-2016). Finally, after 2016, rival left counter narratives joined hands in order to preserve the secular and liberal values of JNU student activism, against the concerted attempts by state and administration-led Hindu nationalists to eradicate them (Martelli 2018).

Figure 1. Political Affiliation of Elected Presidents of JNU Students' Union 1971-2020

\begin{tabular}{llc}
\hline Student Organization & Parent Political Party & Number of Presidents \\
\hline SFI & CPI(M) & $23(52.38 \%)$ \\
AISA & CPI(ML) & $12(21.43 \%)$ \\
FT & None & $3(7.14 \%)$ \\
AISF & CPI & $1(2.38 \%)$ \\
NSUI & INC (Congress) & $1(2.38 \%)$ \\
ABVP & RSS & $1(2.38 \%)$ \\
Other & None & \\
(Non-affiliated org.) & (Indep. or renegade) & $5(11.91 \%)$ \\
\hline Total & & $46(100 \%)$ \\
\hline
\end{tabular}

The main elected student organisations are: SFI: Students' Federation of India, student wing of Communist Party of India Marxist CPI(M),

AISA: All India Students Association, student wing of Communist Party of India Marxist-Leninist $\mathrm{CPI}(\mathrm{ML})$,

FT: Free Thinkers, independent student organization,

AISF: All India Students Federation, student wing of Communist Party of India CPI,

ABVP: Akhil Bharatiya Vidyarthi Parishad, student wing of Rashtriya Swayamsevak Sangh RSS,

NSUI: National Students' Union of India, student wing of the Indian National Congress.

Other student organisations at JNU are:

DSF: Democratic Students' Federation, associated with Left Collective and Youth Bengal,

BAPSA: Birsa Ambedkar Phule Students' Association, sympathizer of the Bahujan Samaj Party BSP,

DSU: Democratic Students' Union, supporter of the Communist Party of India Maoist CPI(Maoist)

UDSF: United Dalit Students' Forum, sympathizer of the BSP Bahujan Samaj Party BSP.

In the shadow of these major historical developments, various different historical subphases animated student political life at JNU (Martelli 2018). First, the repression against JNU students by the police under former Prime Minister Indira Gandhi's regime led to the establishment of an anti-Congress front on campus (1975-1983), structured mainly by the competition between the Students' Federation of India (SFI)-affiliated with CPI(M)-and the Free Thinkers (FT). In the wake of the then student movement spearheaded by veteran freedom fighter Jayaprakash Narayan in various North Indian states, FT introduced to JNU student politics more vernacular understandings of the left, notably through popularizing the Lohiate socialist tradition (Anand Kumar, interview 2019). While "opposing" the left, FT incorporated many liberal and argumentative values of the left. For example, a press report of a JNUSU presidential debate notes that "The organization [FT] would work towards restoration of the 
tradition of debates and seminars in JNU" (PaRChA archive N-968, 1992). Back in the 1970s, the emerging grammar of JNU political competition was structured by the contest between SFI and FT, although a third Trotskyite group, the Marxist Forum was there to "inject serious discussion on history of communism" (Gyan Prakash, interview 2019). Second, for an extended period of time, the dominance (see Figure 1) of the SFI was challenged by mostly independent student groups including FT (19831991). Third, these contending non-affiliated groups-which range from FT to Solidarity-were progressively replaced on campus by pan-Indian student organizations. These included the Congress-led National Students' Union of India (NSUI) and, more importantly, the Akhil Bharatiya Vidyarthi Parishad (ABVP) (19912004), i.e. the All Indian Student Council, which is affiliated to the student wing of Rashtriya Swayamsevak Sangh (RSS) (the National Volunteer Organization) which is the leading organization of the Hindu nationalist Sangh Parivar (family of such organizations).

The growing institutional and political pressure on activism led JNU student organizations to re-examine the well-established campus cleavages within left political outfits. In a first of its kind alliance, in September 2016, the CPI(ML)-affiliated All India Students' Association (AISA) and the SFI joined contested students' union elections together (India.com, September 7,2016). A year later, a splinter group of SFI, the Democratic Students' Federation (DSF), joined the alliance and in 2018 All India Students' Federation (AISF) decided to do the same (Press Trust of India, September $5,2018)$.

Running parallel to this is the emergence of a new Dalit-centric oppositional force on campus, the Birsa Ambedkar Phule Students' Association (BAPSA). BAPSA participated in the student elections for the first time in 2015 (Kumar 2018) with spectacular electoral results in 2016 and 2017. BAPSA eroded the reach of the left by building on the support of marginalized sections of the campus (Imran 2018) against what they portray as Savarna (non-outcaste Hindus, in particular forward castes) Marxists (Shobhana 2016).

Overall, the turn toward liberalization of the 1990s and the progressive decline of parliamentary communism in India-except in the state of Kerala-have transformed Indian society and politics while gradually narrowing the political alleys of Indian left activists. Consequently, the ideological backbone of JNU student politics has become increasingly alienated from the overall Indian political landscape. For many, dominant student politics at JNU now appears as ideologically "dissonant" and inherently antiestablishment (The Economic Times, November 4, 2015).

31 Keeping this in mind, I use the social movement analytical lens to outline the processes by which such political dissonance has been historically constituted. I place emphasis on the importance of political competition in forging and circulating dissenting political idioms on campus. The common empirical thread of the investigation will be student politics around gender issues at JNU, but a few inroads into campus debates on social inclusiveness and environmental activism will be included in the analytical matrix. 


\section{Evidence of Political Spillovers: Outbidding Processes at JNU}

Soon after I arrived on campus in 2014, I started interviewing a small group of gay, lesbian and transgender students with higher urban educational credentials who had decided to oppose the institutional discourse on gender at JNU. Dhanak (rainbow), a queer collective created in 2012 as a private support group, had decided to "come out" and hold public meetings soon after the Supreme Court of India temporarily recriminalized same sex intercourse on 11 December 2013 (Vikram, interview 2015; see also Ghosh 2017). Taking over Anjuman, a defunct queer organization started in 2003 advocating the recognition of gender identities going beyond male/female dichotomies, Dhanak members felt that campus representation neglected nonnormative sexualities and the stigmas attached to such orientations. In this subsection, I present the case of Golu-a frail and usually taciturn man from Rajasthan-who had learned, according to his friends, to assert his gay identity while studying his MPhil and $\mathrm{PhD}$ at JNU:

So we [Dhanak] wanted to be safe, safe, safe. Then what we heard was this complete inaction and complete othering, which was being done by the Students' Union, which was the point where I got very furious and we had this meeting and we decided that probably it is high time that the campus really needs to know that there are queer students in this campus. [...] In a department like mine, [in which] the only form of inequality we talked about were poverty and unemployment and all these issues, which are very relevant issues. Nobody... or gender, if we talked about women issues, never talked about queer issues... Never a mention. It's like we have... complete ignorance and dis-acknowledgement of the fact that thing... even can exist.

The goal of Dhanak-which a couple of years later became inactive due in part to internal conflict-was not only self-representation but to be represented better by existing student organizations. Dhanak supported the SFI candidate for the election of the two student representatives in the then $\mathrm{GSCASH},{ }^{5}$ and the candidate in turn criticized the rival organization (AISA) accusing it of "suffocating diversity" on campus (SFI pamphlet, September 3, 2014). Dhanak served in 2014 as a queer pressure group, lobbying for a shift in the safety-based discourse on gender and advocating for practical reforms such as the increase in number of queer sensitive staff in the JNU counseling cell and the setting up of AIDS screening material in the campus health center (Dhanak pamphlet, April 9, 2015).

The way in which queer activists affected representation was utterly performative; it involved the organization of queer movie festivals, the "rainbowing" of the campus (coloring the campus trees, stairs and building with the colors of the LGBT+ flag) and the reading of personal material (poems, diary entries, songs) in order to make their issues known to students and affiliated activists.

One such event was "Talk to me," a public performance organized by Dhanak a day before the University General Body Meeting-the public meeting in which GSCASH contestants go on stage to address JNU students. On this occasion Andheri, the initiator of the Dhanak group, began talking first and after a couple of minutes, he removed his tight superman t-shirt to reveal another one, pink in color. The scene, symbolizing his coming out in a "hetero-patriarchal" environment was witnessed by a crowd of 
students and most of the GSCASH candidates. Members of the Dhanak group and a couple of outsiders came to the center of the circle and told their stories.

In between personal narratives, affiliated candidates across the board showed their interest in the queer movement. Taking the initiative to question the activists, several contestants displayed a diligent curiosity; SFI candidate Kotaya asked what the letter "I" in the acronym LGBTIQ stood for and AISA candidate Shrini requested the definition of the concept "intersectionality." In the attempt to represent queer interests, left student groups had to win the trust of the queer group. Political activists, in particular those with a left affiliation, worked hard to champion the LGBTIQ cause. Golu made no mystery that the final goal of the meeting was to educate the left on the queer issue:

Later on what we found was everybody, every person who was contesting for GSCASH started talking about it all of a sudden, without probably even understanding what queer rights is about. This is why we had to organize last year this event called 'Talk to me.' Just before the GSCASH election we came up with this... where we invited all these contestants, who were contesting for the post of GSCASH to come to us because everybody was talking very progressive-we want gay rights, we want lesbian rights-but do you understand what exactly are you going to do?

In order to further outline political spillovers in campus, I use text analysis as an inductive tool for grasping semiotic differences (McKee 2003) in pamphlet-writing on campus. Concretely, I present word distributions in the PaRChA corpus to outline relevant salient features (Mayaffre 2016). Here, the mix of ethnographic and textual insights embraces a common epistemological framework, as both approaches account for the subjective meanings of social action, student activism and political learning (Bray 2008; Yanow and Haverland 2012). Pamphlets were categorized according to the authoring organization and year of release, and subsequently measurements of over/ underrepresentation of select words in these categories were computed using the French software of lexicography TXM (Léon and Loiseau 2016, Gréa 2017, Pincemin 2018, Heiden, Decorde and Pincemin 2018). The text analysis method within an inductive research framework enables to synthesize and break the linearity of text in order to identify contrasting lexical patterns while enabling a contextual reading of such features (Duchastel, Paquin and Beauchemin 1992, Mayaffre 2014, Beaudouin 2016). Since text analysis does not inform us about the social conditions of production of political texts and the rituals attached to them (Bourdieu and Chartier 1985:270), the results it can generate are best comprehended when using a broader ethnographic lens.

In 2014, AISA, SFI, AISF, DSF, NSUI and DSU (See Figure 1) abundantly mentioned the lemma (head words as they appear in a dictionary, i.e. write, writes, and writing are forms of the lemma write) "queer" in their pamphlets. Among the JNU activist material I collected as part of the PaRChA initiative, nearly 56 percent of the total use of the word "queer" (or its plural) in the recent history of JNU pamphlets (1994-2014) was in 2014 only (Figure 2). It was not only Dhanak's lobbying that successfully impacted the gender discourse on campus, but also the outbidding strategy of the various student organizations present on campus. Every political organization wanted to show the progressiveness of its own ideological understanding and this resulted in their attempting to be the flag-bearer of the queer cause. Dhanak, however, was not ready to support every political organization making statements about their queerness. At the 
GSCASH election in 2014, the group decided to support the SFI candidate Kotaya and waved the rainbow flag while she was giving her official candidate speech. Subsequently, after Kotaya was elected, Abu and other members of Dhanak came to congratulate her for championing the rainbow cause (Figure 3). Far from being shortlived, discussions around the "queerification" of campus were nested within broader discussions related to gender issues, which gained tremendous prominence on campus. As indicated in Figure 4, the weight of this topic accounted for 50 percent of the total weight of other topics contained in the corpus of pamphlets in years 2013-14. ${ }^{6}$ Such a topic includes words such as women, sexual, struggle, gender, justice, rape and harassment. The extent of focus on this particular issue was unprecedented except in 2001, when a JNU council had approved of the Gender Sensitization Committee Against Sexual Harassment (GSCASH)(2001)).

Figure 2. Co-optation of the Queer Agenda: Lemma Count of Queer in JNU Pamphlets (1994-2014)

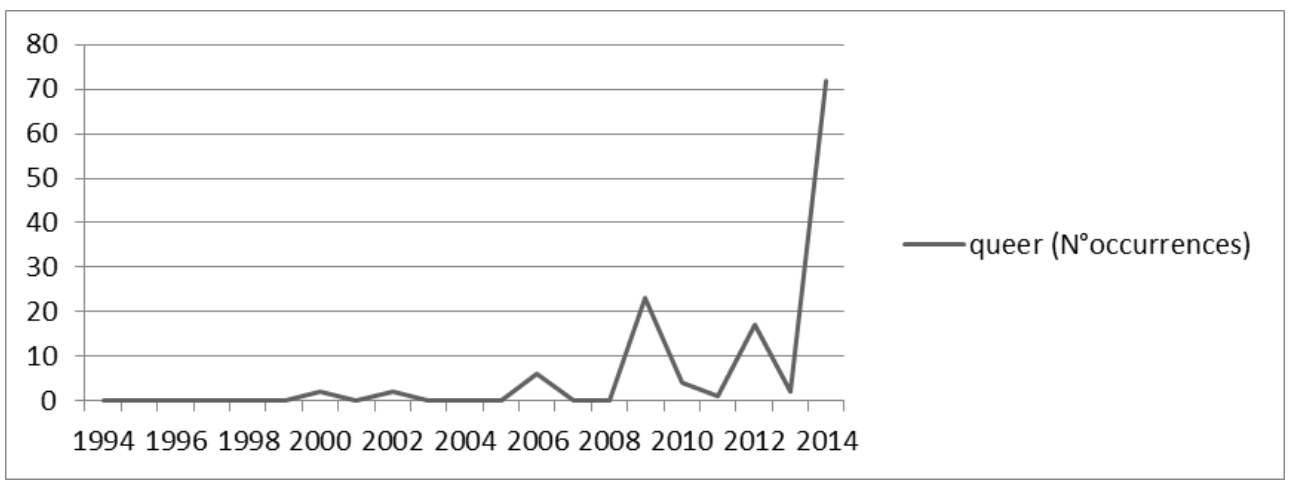


Figure 3. Integration of New Political Idioms: Queer Activist Congratulating SFI Activist (left) for her Election as GSCASH Representative (right), 2014
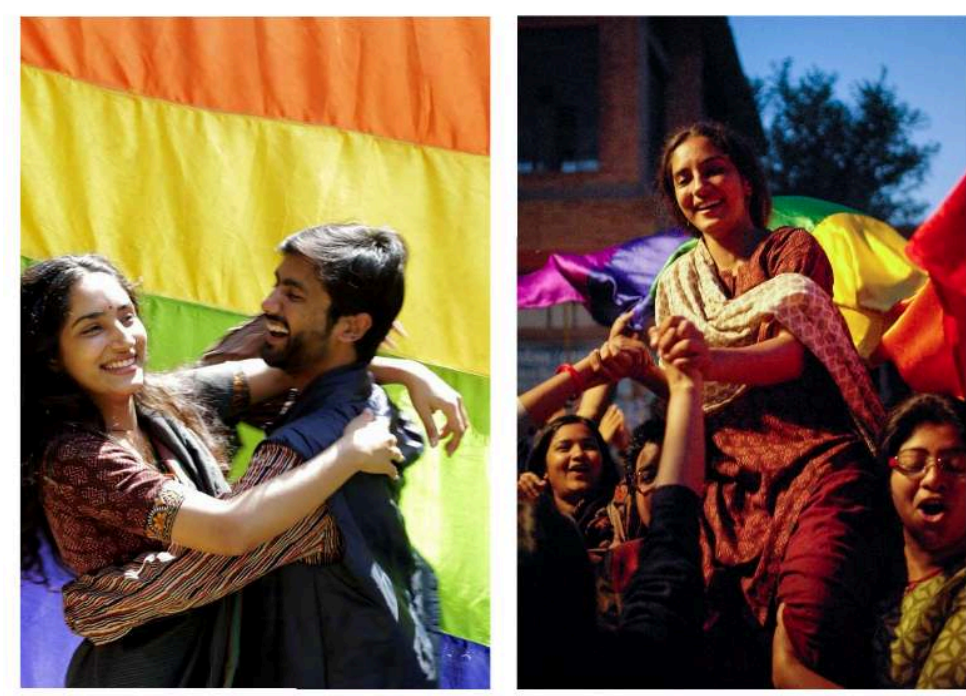

Photo credits: On the left, courtesy of a JNU student, on the right, photo by the author.

Figure 4. Weight of Topics of Gender and Reservation in the Pamphlet Corpus

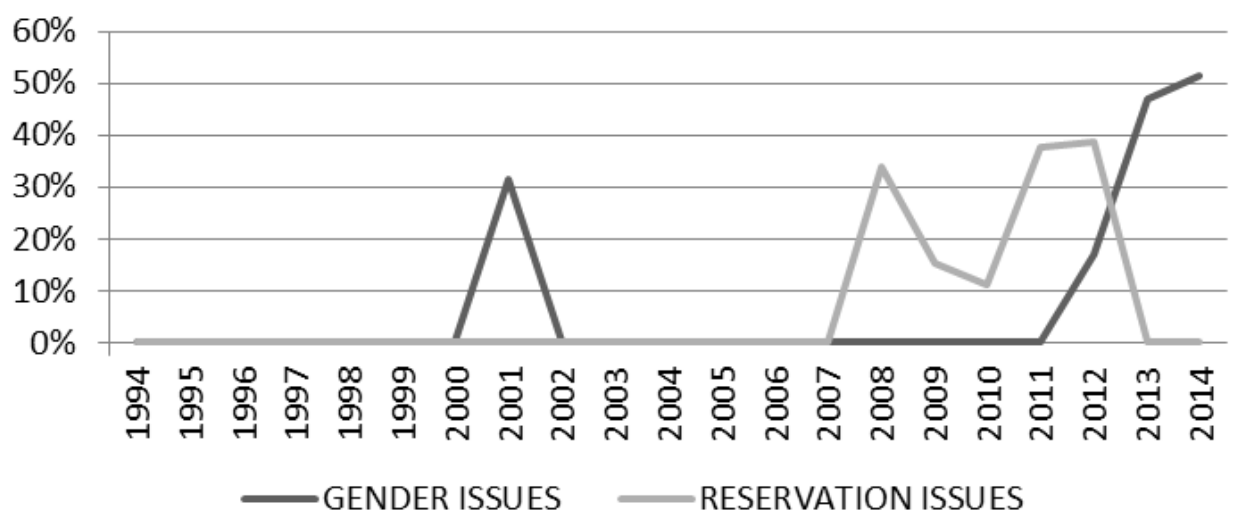

Select predictive words for the topic "Gender Issues": gscash, women, sexual, struggle, gender, harassment, committee, recommendations, rape.

Select predictive words for the topic "Reservation Issues": OBC, reservation, protest, seats, reservations, increase, implementation, intake, court, deal, category.

This case illustrates the competitive and dynamic way in which the ideological understanding of gender is constituted in the campus space. It not only provides a case of how student outfits "absorb" political idioms of exogenous groups; it also demonstrates how specifically social understandings are diffused when indexed by political rivalry on campus. 
41 championing the queer cause. While such outbidding processes are not specific to university spaces (Bajpai and Farooqui 2018), the residential nature of the campus makes the competing queer representation claim by student organizations particularly visible and efficient. Through queering they discourse, they contribute to "mainstreamize" queer politics and vernacularize certain queer understandings of gender identities and relations beyond a certain liberal-elite social niche.

The circulation on campus of new understandings of political idioms such as alternative sexualities relies on strong partisan cleavages from which competing statements on gender relations and identities emerge. Adding to this, the following abstracts from select JNU pamphlets (Figure 5) reveal the organizational competition to claim the leading role in the creation of the aforementioned GSCASH, a body that has symbolized political dedication to gender-related issues. GSCASH was created in the aftermath of the Vishaka Guidelines, the procedural guidelines for use in cases of sexual harassment promulgated by the Indian Supreme Court in August 1997. While these guidelines were implemented by the JNU administration when SFI and AISF were heading the JNU Students' Union, AISA also claims it inspired the creation of GSCASH. As for gender, the requirement of displaying a political history in tune with one's current organizational narrative applies to other topics also.

\section{Figure 5. Example of an Outbidding Process: Pamphlets Arguing over the Creation of GSCASH}

Backtracked from Movements Against Sexual Harassment

In 1996, several demonstrations and gheraos, with many women participants, were held to demand punishment for sexual offenders, but the SFI and its JNU representatives routinely pulled out of each of them. Further. when AISA, in a leaflet dated 19.07.96, demanded an autonomous, non-Proctorial Body to deal with cases of sexual harassment, the SFI kept insisting that the Proctoral Board would do. Only when AISA publicised the Supreme Court Guidelines and held discussions, did SFI finally come around to support this demand.

Excerpt from AISA pamphlet, 16 November 1999, ID-1616 (argument 1, reference below)

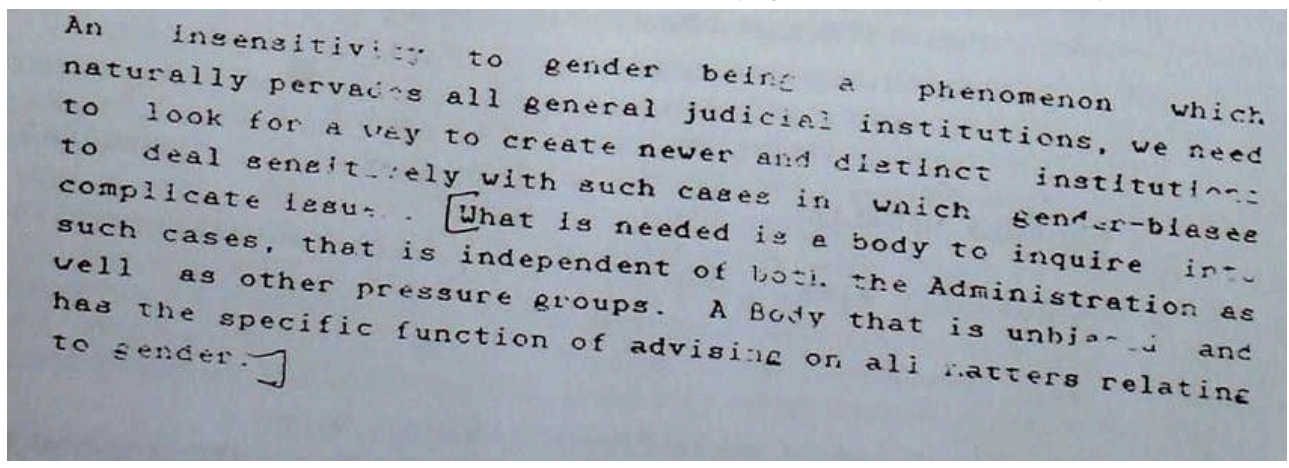

(2) Excerpt from AISA pamphlet, 19 July 1996, ID-60333 (original reference)

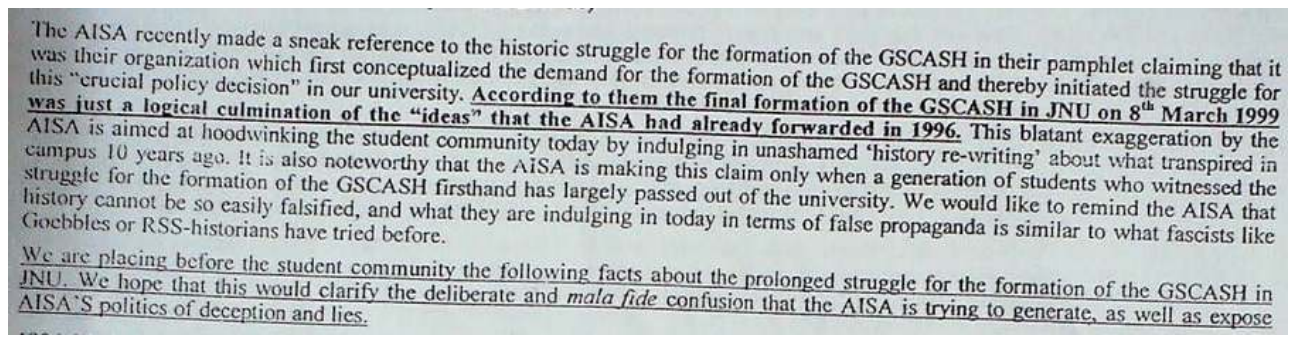

(3) Excerpt from SFI pamphlet, 16 September 2006, ID-68362 (argument 2, reference below) 
On the $8^{\text {th }}$ of March in 1908 , thousands of women needle workers marched on the streets of New York demanding suffarage for all women and 8 working hours in a day. This historic strike gave a call to all socialist and women's organizations to observe the $8^{\text {th }}$ of March as the International Women's Day. Since then, struggles against coersive, right reactionary, patriarchal forces have made themselves felt all around the world. Last year, the International Women's Day marked the initiation of a significant struggle by the JNUSU. An open convention was held on 7.3.98, to discuss the menace of sexual harassment. Following the Supreme Court guidelines, a comprehensive draft proposal of a Gender Sensitization Committee Against Sexual Harassment was prepared. However, the struggle for the constitution of GSCASH was not an easy one. The Student Community had to oppose the Sexual Harassment Committee formed by the administration along with launching signature campaigns, demonstrations and indefinite hunger strikes. Today's International Women's Day marks an important milestone in this struggle when the administration has been compelled to finally constitute GSCASH along our proposal. The JNUSU congratulates the JNU Students Community for its staunch commitment to the struggle for a gender sensitive campus.

(4) Excerpt from SFI (JNUSU) pamphlet, 8 March 1999, ID-61717 (original reference) most part refrain from disclosing their drinking habits to common students), the initiative received some support from highly educated students, leading established student organizations to label them as "elite" when they decided to organize a meeting with alcohol in the open. Drumi, a JNU PhD student summarized the spirit of the initiative: "GSCASH does not have the vocabulary to address this, and the organized left will not take the risk to alienate part of their constituency [...] It [GSCASH] is not only about women, it is about privacy, condom machines, security." A section of the pamphlet reads as follows:

\begin{abstract}
What does it then imply when the left, and many others, label these concerns as that of the elite? But are questions such as the right to one's own body, the spaces it inhabits, and the desires it expresses questions of privilege? We think differently. The left's penchant to quickly "class"ifying issues does not always work....The figure of an "elite" or the "privileged" is an ever shifting one because it is relative.... We must understand that in the garb of calling something "elitist" probably there exists a deeper kind of Moralism. The working class becomes the forbearer of this Moralism along with revolution. Can the Left therefore begin to think of an immoral revolutionary? (Indecent proposal pamphlet, April 15, 2015).
\end{abstract}

This case, echoing the claims of the autonomous Delhi-based women's collective Pinjra Tod (break the cage) (Martelli 2017) exemplifies that not all the claims advocated by non-affiliated student groups are integrated by electoral student organizations on campus. It demonstrates, however, that the politicization of students' attitudes, fueled by institutional competition among student groups, also permits the emergence of new political critiques, thus contributing to debates grounded in the JNU campus space.

For the most part, student activists themselves acknowledge the importance of everyday political competition, indicating that such routinized activity turns the campus into a distinctive political space. For instance, in the wake of the post-2016 
repression on student activism and the need for left organizations to join hands, Lakshmi, an SFI activist acknowledges that:

I am actually against that alliance [between left organizations]. In the unit [SFI deciding body in JNU] I said the same. Of course, it makes sense in Modi times... and considering the current situation in campus. Look, we are now discussing [with an activist from another organization] on the roof of Brahmaputra [hostel]. That doesn't matter. But because of that [alliance] we don't politicize like before, we are not strengthening the organization, we are lazy and we know we will win anyway. How many programs are there [organized by student organizations]? Hopefully next year we [SFI] will contest separately... after Mamidala [JNU Vice Chancellor] goes...it's not a bad thing for the campus and the left. The JNUSU contest brings energy, the kind of hardcore work we do, cannot happen within the alliance. Apart from being harassed by the administration, we get sleepy, we don't talk to students as much as before, we are quite passive. So the result... the campus is kind of apolitical... less political at least... just sleepy and depressed.

Questioned on the matter, former JNU activist Azad agrees with Lakshmi's argument:

[Lakshmi] has a point, that, if there is a fight between left organizations, there will be more mobilization, more political equality, more aggression and energy, but if we come together, less organization, less energy, because people have already made their mind that they will vote for left, so in the recent years, they didn't campaign room to room. Earlier it was like, when there is a fight between AISA and SFI, room to room campaign was very rigorous, and it has politicized campus in one sense. In another sense they have undermined BJP.

The impatience of Lakshmi regarding the restoration of traditional intra-left competition becomes understandable when taking into account the broader effects of electoral competition on the politicization of students. Indeed, Lakshmi envisions the possibility of political participation through reenacting campus political cleavages. While keeping the focus on the political debates on gender at JNU, and in order to further understand the way in which dissonant political understandings are forged in campus spaces, I will now examine the cross-fertilization between political ideas on campus. I argue that campus politics becomes further distinctive when it favors the intimate ideational pollination between competing student groups. As long as these groups are value-based and not simply interest-based, the intellectual interpenetration between them enables forms of ideological cross-fertilization that foster the emergence of hybrid, thus novel and dissonant political idioms.

\section{Evidence of Political Spillovers: Cross-fertilization Processes at JNU}

"Have they really left from campus?" a student asked with a pinch of irony in the middle of our conversation. Although Nikita and Rajan had "passed out" (graduated) from JNU in the 1990s without completing their doctoral dissertation, many would be able to identify them from their frequent visits to campus. Nikita is not only the only female in CPI(ML)'s higher decision-making body-the politburo-but also the unofficial face of the political organization on social media, a mentor for AISA activists and a prominent figure on gender debates in Delhi. For his part, Rajan had been the AISA political organizer par excellence since the mid-1990s, overseeing the functioning of the campus organization and recruiting new students while making liaisons between 
the student body and the parental organization. While abiding by orthodox Marxist tenets, both have been instrumental in the synchronization of AISA/CPI(ML) in line with other ideological idioms circulating on campus. Both of them would spend precious time convincing me of the imperative of reading contemporary India from a Marxist lens.

We [AISA] can critically absorb things, you open a Russian doll, issues we fight for come out. [...] Marx is beautiful, Marx has thought of everything, don't try to look at Marx in detail, look at Marx in broad strokes. The point is, I understand what he [Marx] says, the potential of his words, the power of his analyses. I can reason out. Out of reason, I have reverence, not the other way around. The common sense has been manufactured [...] people become sceptics without reading Marx, that is the conscious design of academia today, you start the class by saying that Marx does not have answers. They say that on women questions Marx does not have an answer, on environment question Marx does not have an answer, what the hell (Rajan, interview 2014).

Caste is a material reality; workers are fixed to a certain kind of labor. Patriarchy is tied up with economic and land relations, a community will undergo greater strain because women are claiming land, khap panchayats [clan community organization in Haryana] got ruling parties and state governments to make politicians pass laws in their state assemblies to prevent women to inherit property. [...] This is linked to honor killings and rape. When a woman marries outside, that means division of the land. It is structural... part of the social and economic relations. [...] Capitalism in India is interested in subsidizing itself by making women do domestic work. [...] Violence is structural... it comes from the superstructure. [...] The market makes you feel anxious about your body. Freedom equals capitalism... not at all! (Nikita, interview 2014)

What is striking from the conversations is not the political sensitivity towards Marxism or feminism, but the way readings of both ideologies are woven together in a dialogical fashion. Through attempts to trace the genealogy of such intellectual dialogue, Nikita acknowledges that it is JNU that taught her "everything" and that her political commitment towards gender issues emerged in tandem with her concern about class relations in India.

Strikingly, the genealogy of the interpenetration of feminism and Marxism in the All India Progressive Women's Association's (AIPWA, the CPI(ML) women branch) ideology brings us back to the JNU of the 1990s. Looking for such evidence, I stumbled on the following paragraph in an AISA pamphlet from 1997 authored by Nikita herself (see Figure 6 for the full pamphlet):

Free thinking feminism, which, since it does not define itself as Marxist, necessarily has no consistent agenda for social change; and is thus in no position to change patriarchal structures. This leaves them in the position of defining sati [widow immolation], dowry, or rape as evils in a basically good society rather than the symptoms of an oppressive class-divided society. This deplorably inadequate position is paralleled by a "Marxism" which refuses to see the specificity and materiality of gender oppression and thus refuses the need for a feminist politics. AISA reiterates the need for Marxist Feminism and a feminist Marxism as integral and synonymous parts of our ideology and struggle (Krishan and Tanweer 1997). 
Figure 6. Cross-fertilization of Marxism and Feminism: AISA Pamphlet, March 1997 (ID-40753 \& ID-40752)
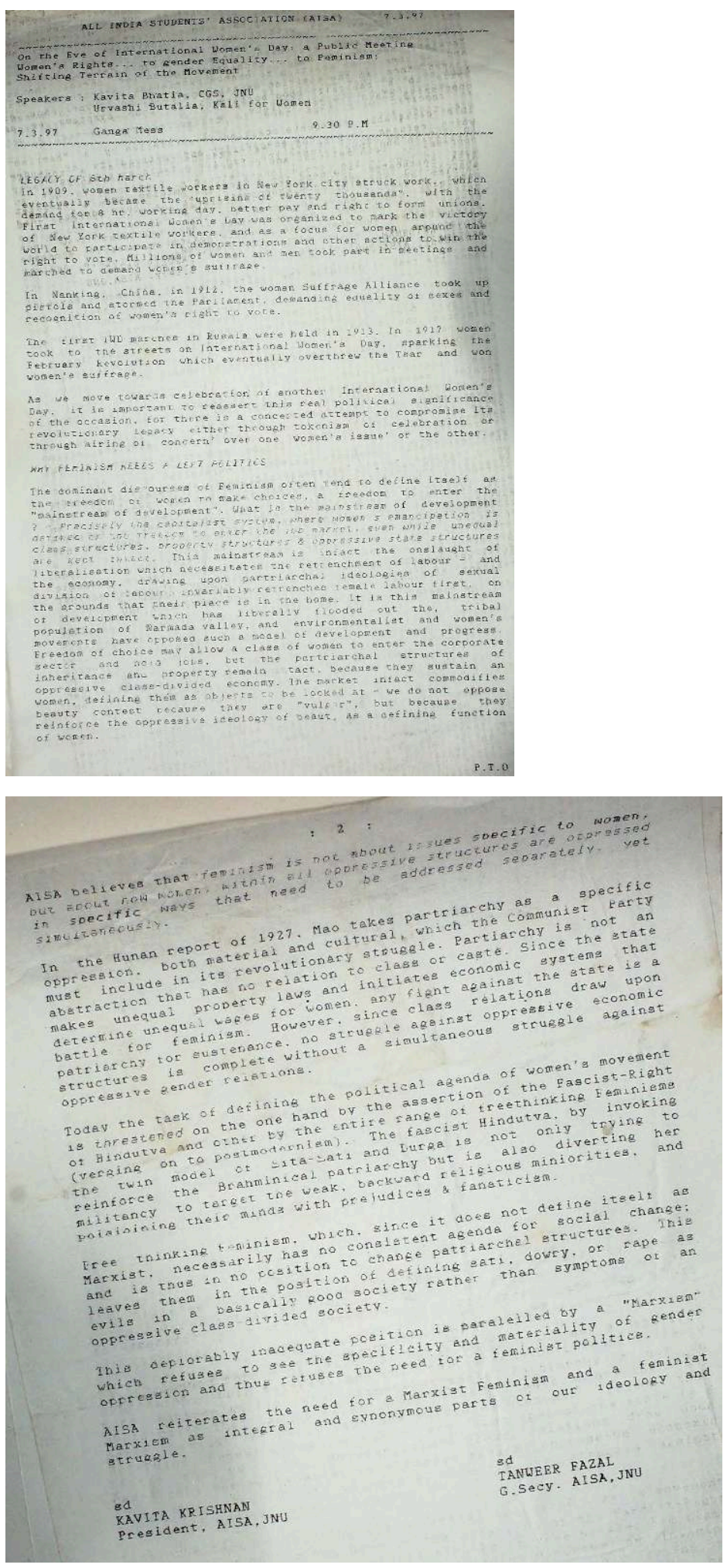

This pamphlet not only exemplifies how central the JNU campus is in the formation of the core ideas of a wider political organization; it also outlines the importance of how campus-based ideological cross-fertilization permits the emergence of innovative interpretations of gender. In addition to Marxist feminism, other examples of 
ideational inter-breeding emerge on campus. Examples of political meetings advocating for a "Socialist political ecology" (cf. Figure 8) confirm the significance of crossfertilization in the development of campus-based political dissonance. In fact, several cases exemplifying the existence of tactical strategies that enable student groups to "appropriate" rival political messages are found on campus. To illustrate this, I introduce two new cases.

The ABVP discourse is mainly based on Hindu nationalism aiming at "eradicating" the communist influence on university campuses (Jaffrelot 2007:18) while diffusing RSS core ideas, even when the paternal organization, RSS, is under attack (Govindacharya, interview 2019). However, interviews with right-wing student activists bring to the fore occasional, yet striking attempts to display left-leaning political arguments. It is possible to assume from their account a certain standardization of acceptable views on topics like women and queer rights, socialism, rights of marginalized castes and democratic deliberation, across organizations on the left and right of the political spectrum. Birendra, a JNU student and former Delhi University (DU) treasurer of ABVP unit would admit telling certain students that: "Off the record, I am Marxist; like [the deity] Ram, my concern is how to feed people... promote equality."

In many respects it appears that, to a certain extent, ABVP members in JNU displayed values that conflicted with some of their own organizational leadership outside of campus. One ABVP JNUSU presidential candidate admitted to me his socialist leanings: "Here ABVP is socialist in character, I cannot deny it. We want freedom for girls, reservations for deprived based on economic grounds, more democratic rights... Not like those communists who prevented ABVP to talk in the last anti-Modi march" (Hrishabh, interview 2014). Another PhD student and ABVP activist, very active in the years 2007-2008, openly criticized caste humiliation perpetrated by Brahmins: "ABVP embraces the liberal values against caste oppression. At the time of my grandfather Dalits were not allowed in the house [...]. My father let them in but then they have to sit on the floor. When dad was not in the house I allowed Dalits to sit on the bed [...]. I am fighting inside the party to make insulting behavior stop" (Bharat, interview 2014). This reluctance to support religious and caste violence was persistent in my interviews with ABVP activists. Bharat, who was seen with other ABVP activists throwing stones at a Dalit JNUSU candidate back in 2007 (Singh 2007a, 2007b), was now claiming he was fighting within RSS to stop insults against Dalits and Muslims. Commenting on a then fresh anti-Muslim incident-a nativist Shiv Sena Member of Parliament, complaining about the food he was served, had force-fed bread into the mouth of a Muslim caterer fasting during Ramadan-Bharat replied to me, "this is just unacceptable, I will not let these things happen."

Some ABVP activists like Saharsi, former candidate in a Delhi University student election (and also incidentally, my roommate for several months at JNU), gave examples of the difficulty of reconciling RSS ideology with the values internalized on campus. For instance, one day, while commenting on the series of forced conversions of Muslims, labeled Ghar Wapsi (home coming), carried out by a Hindu group in Agra, the Dharam Jagaran Samiti (Religious Awakening Committee), Saharsi expressed to me his deep unease:

Ghar Wapsi... they are some VHP [Vishva Hindu Parishad, another right-wing Hindu nationalist organization] people who do that, I don't like it. They are also some fringe elements, Sakshi Maharaj [i.e. a notoriously controversial 
$\mathrm{MP}$ ] in BJP for example. But I think India is the most inclusive country. That does not mean that government is patronizing reconversions. The government is actually concerned, look this year [there was] no violence on Valentine's Day [day in which couples appearing in 'romantic' places are at times attacked by Hindu nationalists]... Of course I oppose government's forceful conversion. If Muslims were doing that, then some Hindu would be converted forcefully. So far I have not found RSS guilty or even involved... but somehow yes they support that actually. I think there should be a genuine [i.e. different] voice [coming] from RSS. ABVP should not follow blindly what RSS says. It is very difficult to defend ghar wapsi [reconversion to Hinduism], but because of RSS some feel obliged to defend that in public. personal convictions of some of its members, such as three ABVP office bearers, who in February 2016 decided to resign from their posts. In a pamphlet they denounce the "hooligan" behavior of the government and, most importantly, the opposition to protests against academic authorities that led to the suicide of Rohith Vemula. The pamphlet concludes by stating two traditionally opposed slogans, one of the ABVP rallying cry Vande Mataram (Mother, I bow to thee) and one of the slogans of the proponents of Dalit leader Bhimrao Ambedkar, Jai Bhim (Victory to Bhim). The author of the pamphlet later (2019) referred to his left leanings within the ABVP as follows:

\begin{abstract}
My personal experiences in JNU overpowered the broader understanding we should have built up back then in my village in Haryana. [...] Society is conservative, feudal, casteist, getting in ABVP is easy, natural. [...] I am a very left Ambedkarite person. When I was contesting for the election from the ABVP, Hassan [a left political opponent] was asking me: what about the beef festival in Kerala that has been vandalized by the ABVP? All these things, blah blah, meat festivals and all. I said, everyone has the freedom to eat anything. I condemn that [the vandalization]. People said he [referring to himself] is a soft sanghi...he is a left sanghi! [...] I believe in the ethos of Marx, Bhagat Singh, Ambedkar, Nehru, Gandhi. We wanted to change the status quo, the hierarchy-based system, the feudal system. I wanted to change society, so I became left.
\end{abstract}

The paradoxical leftist imprint on ABVP worldviews in JNU is best exemplified by Nidhin, a once ABVP JNU student who is now a pro-RSS professor holding high administrative responsibilities in the university. He defines himself in opposition to the left who "forces students to de-Hinduize," but simultaneously shows emotional attachment to liberal "leftist" values. While the post-2016 scenario has reinvigorated the official anti-national narrative inside and outside campus, it is still the liberal ethos forged by the left-paradigm in campus that continues to inform the ideological formation of the JNU-ABVP (Chotapatra, interview 2019, Shibak, interview 2019). Nidhin's account not only demonstrates the cross-fertilization of political idioms across organizations (quote 1), but also shows the centrality of an activist's ideological competition in shaping his political identity (quote 2).

See I am a different kind of right wing, who talks like a leftist. You know questioning ideas, questioning things, we have to be critical. You know sometimes people say that there is a little bit of red in everybody who studied in JNU. There is a little bit of red in me. The touch of red is that I want to open a bar [laughter]. In my time we used to have beer in front of the library canteen. We were nice, well behaved. [...] Now I am [name of the 
administrative position], what a contradiction [laughter]. [...] If I was a VC, I will never do this [i.e. to remove the political posters put up by student organisations on JNU walls], this is not good. Same regarding the crazy fees of the School of Management, I expressed my views. [...] This is the 6th year of Modi government, I could have gone up very fast, but I want to give myself the possibility to move away. [...] The politics of the cow, I find it irrelevant and absurd. It should not happen. [...] In fact, my ideologue was Vajpayee, he was very moderate. [...] People like me are vulnerable, left want to finish you at the first opportunity, and also a lot of moral conflicts arise. [...] Vidrohi [left ascetic poet who lived in JNU] never took money from non-leftists. But then I realized he liked me for some reason. He was asking money from me in fact. See he lived his all life with principles. He was a staunch leftist, but he never compromised.

JNU made me speak [...] I was extremely introvert, in my first year in Peryar hostel I spoke to two people from my village for the entire year. The year after I was contesting for the post of GSGASH. [...] It was a humiliation, that one girl was asking "did you have lunch" [reference to his lack of energetic assertiveness while approaching student voters]...Clearly, I was not loud enough during my campaign. [...] JNU transforms you, whether you are right of left. [...] Perhaps, if I had not fought against the left, my personality would not have developed. [...] Everyone wanted the other to talk. [...] There was a hostel mate who read one of my poems on my father [he recites his poem]. He was a staunch left ideologue and activist pretty involved and we decided that we will meet at 9:30 [pm] after our dinner and so after my dinner we met outside the hostel gate and he said okay, come to my room, and we started talking and talking and talking till 6 in the morning. And he said that, should we have some tea? I said why not...so we walked outside the campus till Katwaria Sarai which is almost 2 kilometers from the campus, we went there, we had tea, we came back and we shook hands before separating, just saying that: 'I think we are different'. So, it's a great feeling, it's a great experience of life.

In all likelihood, the aforementioned Jai Bhim slogan is a symbol of ideational crossfertilization, as it is not only coopted by the main Hindutva student organization, but also by the left collectives-in particular in the aftermath of the 2016 crackdown and the emergence of the Birsa Ambedkar Phule Students' Association (BAPSA) as a strong political rival (Pallikonda 2018; Kumar 2018).

Such a semantic turn indicates a strong aspiration by the electoral left to reappropriate the Dalit "heroes," the anti-Brahmanical figures and the anti-caste social reformers. Such contest over the representation of the Dalit community can be identified in JNU pamphlet production. Figure 7 shows that the mentions of the figures Ambedkar (1891-1956), Phule (1827-1890), Periyar (1879-1973) and Shahu (1874-1922)-who are the symbolic ambassadors of discourses on caste empowerment-is clearly not monopolized by community-based organizations such as BAPSA, the United Dalit Students' Forum (UDSF) or the All India Backward Students Forum (AIBSF). 
Figure 7. Cross-fertilization of Ambedkarism and Socialism: Score of Association (Chi 2) between Ambedkar, Phule, Periyar and Shahu Words in Various Student Organizations in JNU Pamphlets

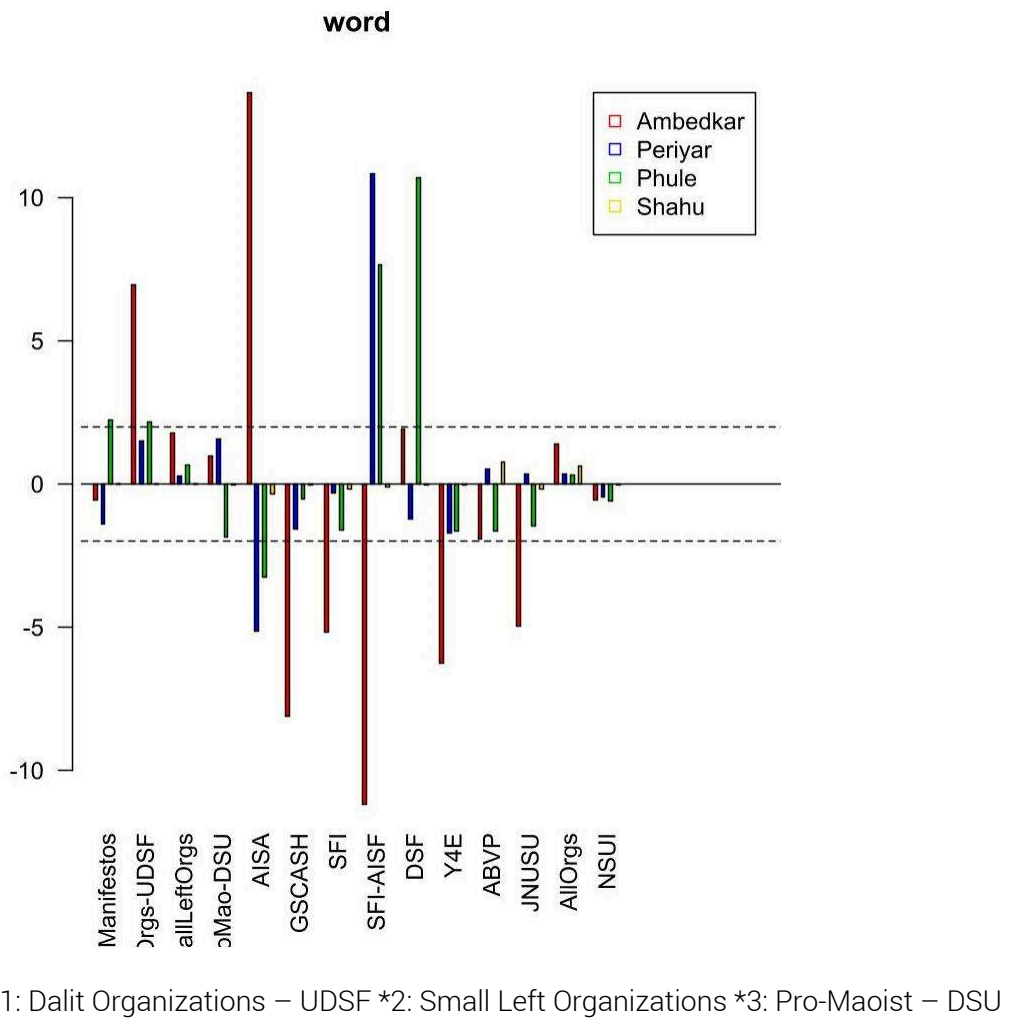

Positive scores for words in Figure 7 mean they are overrepresented in the vocabulary of a particular student organization as compared with other ones in the PaRChA archive. In fact, the organization referring the most to Ambedkar is AISA, and the SFIAISF combined with the Democratic Student's Federation (who have many political references in common) are particularly interested in mentioning Phule. This result is not only evidence of the integration by mainstream JNU organizations of the "socialjustice" political vocabulary; it clearly outlines how ideational political competition on campus spaces enables the diffusion of dissonant political idioms through competitive appropriation. This evidence of ideological cross-fertilization-whether tactical or not -in addition to the process of political outbidding already indicated how campuses can generate on-campus political spillovers that contribute to the emergence of original political imaginations in contemporary India.

The pervasiveness of spillovers and the cross-fertilizing effects they induce in campus should not lead us to consider such spaces as isolated from the broader polity. The scholarship on diffusion in social movements has unveiled multifarious ways by which activist tactics and ideas spread across space (Rogers 1995, Chabot and Duyvendak 2002, Bunce and Wolchik 2006). While some political novelty might emerge from the campus itself through activating and sheltering political "initiators," in other instances student activists in universities might be better understood as "early adopters," legitimizing though their action in a competitive space a set of new ideas that have emerged elsewhere (Tarrow 1998).

It is only through unpacking these processes of contagion that a definitive answer on the origins of political creativity among educated youth in India can be offered. Due to 
the sparse evidence on the matter, this article is not providing a definitive answer on the extent to which Dalit-feminist, left-feminist, and right-with-a-touch-of-left political hybridizations are produced and spread by on-campus political spillovers-rather than imported from outside as replica of the broader zeitgeist. However, the contribution suggests that while there is an indeterminacy on where in the political cycle new forms of political representation are seeded, the existence of on-campus political spillovers facilitates the diffusion and the generalization of political idioms by "early adopters"if not by "initiators" themselves (Roggeband 2004). A good case of political "early adoption" in campus is provided in Figure 8. The two pamphlets displayed are testimonies of the visit to JNU of two leaders of the environmentalist movement in the early 1990s (Sunderlal Bahuguna and Medha Patkar). In the first one, two JNUSU elected representatives assert that Sunderlal Bahuguna was able to "stir in us the realization of our integral and harmonious relationship with nature," which then led to the creation of a "struggle committee" on campus to support the Narmada Bachao Andolan (Save the Narmada River Movement) against the environmental damage caused by the building of dams in Gujarat and Madhya Pradesh.

Figure 8. Cross-fertilization of Socialism and Political Ecology: Letter \& Pamphlet

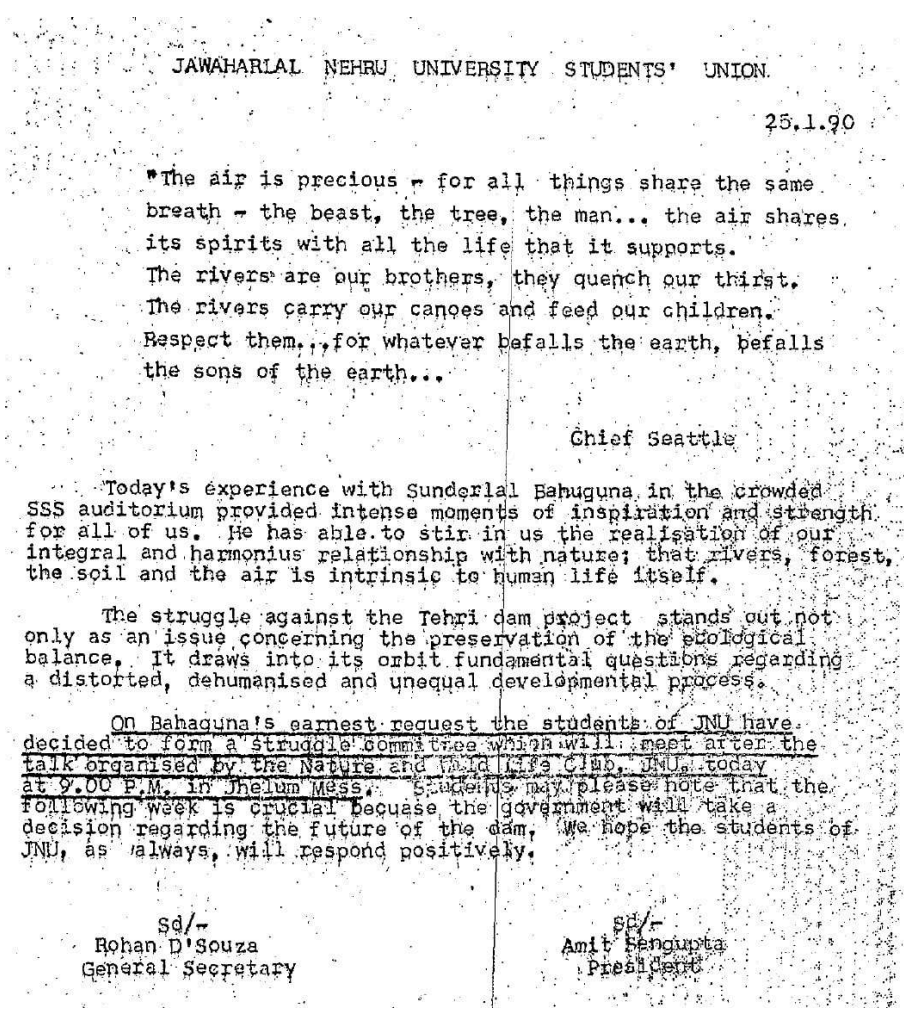




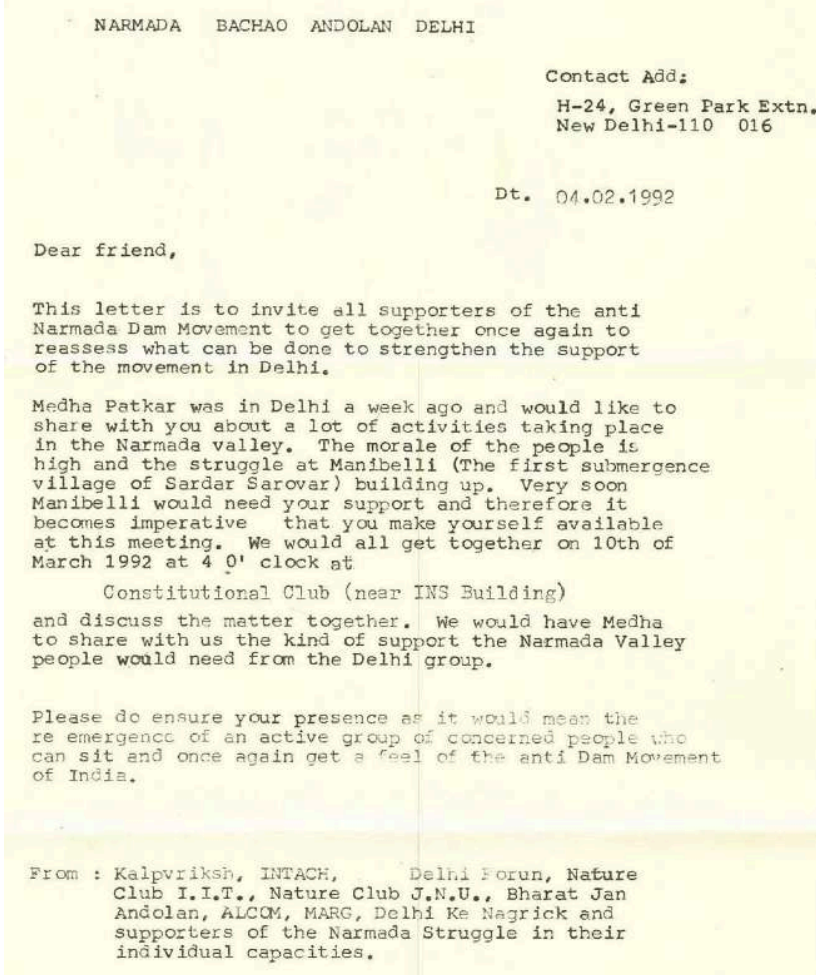

JNUSU invited to a meeting of the Narmada Bachao Andolan, 1992 (ID-90152)

The aforementioned example exemplifies the rootedness of student politics in the broader ecology of movement-based politics outside the campus. While broader networks do inform political spillovers in JNU to an extent, political idioms also travel from campus to a variety of political communities, notably via students and graduates who take active part in wider Indian political affairs, ranging from political parties to NGOs, journalism and public service-while also penetrating informal political networks as well as communities of shared belief. In addition to such direct networks, online social ties and indirect forms of political imitation are also instrumental in disseminating political idioms outside campuses. In an interview (2019), Nithya, a reputed feminist professor-activist in JNU reflects on the articulation between the campus as a space of generative political confrontation, and on its broader imbrication in the larger feminist social movement field.

The campus [is significant], significant is a small word. Being inside a space in which our job is to be critical thinkers [...] younger people are constantly pushing your sense of whatever you think your politics is. As a feminist I think I have travelled a long way from the time I was in my 30s in my understanding of sexuality, sexual harassment, all of this. [...] At a meeting there are not students and teachers and doctors, there are all just feminists. We are all arguing things out. These are overlapping spaces, and campuses have always been one of those. One of the spaces that has been crucial, inside and outside the classroom. [...] You realize that some of your theoretical positions have to be revised. It [campus] is a live space of introspection and challenge. [...] There are a lot of bitter debates [...] those confrontations lead to some new positions. I won't say forward or backward, but something new. [...] I edited a book on gender and politics in India in the 1990s...there is nothing on caste. I didn't exclude caste, I just did not think about caste. [...] There is a way caste enters our lexicon and our understandings and 
transforms us, because of the powerful Dalit voices that became more and more impossible to not hear. Once it happens there is no going back. And campuses are very important spaces for this and there is a critique made of the left, and probably rightly, that the left is, and I guess I should include myself, is blind to the way in which caste operates. [...] there are still issues in which students have challenged people for quoting Ambedkar and saying "you are co-opting him... why should a savarna person speak about Ambedkar?" I treat it as part of the ways in which campus are prickly places, it is not romantic place in which we love each other, it is a place that produces blood among one another. And it is good blood.

Indubitably, the "prickliness" of the feminist debates in JNU-including students and faculty-is the expression of the creative everyday argumentative conflicts leading to self-transformation and the emergence of political spillovers. Yet, according to Nithya, this agonistic process does not emerge ex nihilo, and university should be seen as an "overlapping space" made of the repeated interventions from within and outside campus. All in all, while it is obvious that campus spaces do not have a monopoly over political innovation, it appears inaccurate to negate their political relevance as formative public spheres.

\section{Conclusion}

Contrary to idealistic accounts that provide a stylized depiction of student years as inherently agitational, this empirical analysis has shown that the campus as a shared dwelling space is not in itself a driver of politicization. However, when such ecology fosters ideologically driven competition among student groups, it then becomes a conducive ground for the politicization of educated youth. This article builds on the finding that inter-cohort socialization is central in the emergence of political attitudes on campus (Martelli and Ari 2018). It substantially complements this argument by examining the way on-campus competition between activist collectives is instrumental in the emergence political spillovers, notably through nurturing non-violent outbidding discourses and ideational cross-fertilization among student organizations. Because such political spillovers irrigate the social space of the campus across social cleavages, they concur with the generalization of novel and dissenting tropes in an institution such as Jawaharlal Nehru University.

The convergence of ethnographic and archival evidence offers a counterpoint to the literature that posits higher educational spaces as territories for the reproduction of broader social orders structured around caste, gender or family upbringing. Although it is useful to posit campus life as a mirror of the broader Indian political society, such a stand also tends to undermine the generalizable political features occurring specifically in university arenas.

Through addressing the political dynamics deposited in university premises by generations of student activists, this article suggests that select residential campuses such as JNU are favorable grounds for the activation of political idiosyncrasies dissonant from the larger public discourse. The article does not claim that all residential campuses are dissenting spaces, as the emergence of political spillovers do require an environment of ideational contest in which student groups engage in outbidding practices. However, the structural composition of the campus can facilitate the circulation of political idioms among cohorts of students relatively free from 
exogenous social constrains. In order to better identify the emergence of political innovation from within Indian campus spaces, I suggest that student activism is best understood in a diachronic fashion, through examining everyday processual mechanisms at work in the selective activation, emulation and circulation of valuebased political idioms.

Despite the criminalization of student politics in JNU by the ruling dispensation since 2016, the fact that political spillovers in this campus favor social intercourse based on political argumentation (Habermas 1989:36) has wider implications for the study of Indian democracy. It indicates that JNU student politics, in its capacity as a public sphere situated between the state and the private experiences of youth, articulates political themes that are neither validated nor approved by the ruling Hindu nationalist regime and its media apparatus. The labelling of student politics in many public central universities as anti-national and Maoist serves as a mass communication narrative aiming at controlling ideologically incompatible, yet argumentative and autonomous youthful public spheres. As the regime consolidates its position as the political flag-bearer of a Hindu-centric nation, notably through demonizing pluralist campus politics as in JNU, it places educated youth's experiments with competitive value-based politics as a prime danger to its hegemonic aspirations.

\section{BIBLIOGRAPHY}

Ahmad, Irfan. 2009. Islamism and Democracy in India: The Transformation of Jamaat-e-Islami. Princeton. Princeton University Press.

Altbach, Philip G. 1968a. "Student Politics and Higher Education in India." Daedalus 97(1):254-73.

Altbach, Philip G. 1968b. Student Politics in Bombay. London: Asia Publishing House.

Altbach, Philip G. 1969. Turmoil and Transition: Higher Education and Student Politics in India. New Delhi: Basic Books.

Altbach, Philip G. 1970. "India and the World University Crisis." Pp. 1-27 in The Student Revolution: A Global Analysis. New Delhi: Lalvani Publishing House.

Altbach, Philip G., ed. 1970. The Student Revolution: A Global Analysis. Bombay: Lalvani Pub. House.

Andersen, Morten Koch. 2014. The Politics of Politics: Youth Mobilization, Aspirations and the Threat of Violence at Dhaka University. Roskilde: Roskilde Universitet.

Andersen, Morten Koch. 2016. "Time-Use, Activism and the Making of Future." South Asia: Journal of South Asian Studies 39(2):415-29.

Bajpai, Rochana and Adnan Farooqui. 2018. "Non-Extremist Outbidding: Muslim Leadership in Majoritarian India." Nationalism and Ethnic Politics 24(3):276-98.

Banerjee, Sumanta. 2008. In the Wake of Naxalbari. Kolkata: Shishu Sahitya Samsad.

Banerjee, Sumanta. 1984. India's Simmering Revolution: The Naxalite Uprising. London: Zed Books. 
Baruah, Sanjib. 1999. India Against Itself: Assam and the Politics of Nationality. Philadelphia: University of Pennsylvania Press.

Basant, Rakesh and Gitanjali Sen. 2010. "Who Participates in Higher Education in India? Rethinking the Role of Affirmative Action." Economic and Political Weekly 45(39):62-70.

Batabyal, Rakesh. 2014. JNU: The Making of a University. New Delhi: Harper Collins.

Beaudouin, Valérie. 2016. "Retour aux Origines de La Statistique Textuelle: Benzécri et l'école Française d'analyse Des Données.” Pp. 17-27 in. JADT 2016, edited by D. Mayaffre, D. Poudat and C. Vanni. Nice: France.

Belliappa, Jyothsna Latha. 2015. “The JNU Way.” Economic and Political Weekly 53(33):7-8.

Bhasin, K. 1974. “JNU; The Escapist Heaven.” Femina. July.

Brady, Henry E., Sidney Verba, and Kay Lehman Schlozman. 1995. “Beyond SES: A Resource Model of Political Participation.” American Political Science Review 89(2):271-94.

Brady, Henry E., Sidney Verba, and Kay Lehman Schlozman. 1995. "Beyond SES: A Resource Model of Political Participation." American Political Science Review 89(2):271-94.

Bray, Z. 2008. "Ethnographic Approaches." Pp. 296-315 in Approaches and Methodologies in the Social Science: A Pluralist Perspective, edited by D. della Porta and M. Keating. Cambridge, NY: Cambridge University Press.

Buechler, Steven M. 1990. Women's Movements in the United States: Woman Suffrage, Equal Rights, and Beyond. New Brunswick: Rutgers University Press.

Bunce, Valerie J. and Sharon L. Wolchik. 2006. "International Diffusion and Postcommunist Electoral Revolutions." Communist and Post-Communist Studies 39(3):283-304.

Chabot, Sean and Jan Willem Duyvendak. 2002. "Globalization and Transnational Diffusion between Social Movements: Reconceptualizing the Dissemination of the Gandhian Repertoire and the 'Coming out' Routine." Theory and Society 31(6):697-740.

Chandra, Pankaj. 2017. Building Universities That Matter: Where Are Indian Institutions Going Wrong? Telangana: Orient Black Swan.

Chatterjee, Partha. 2015. "Freedom of Speech in the University." Economic and Political Weekly 51(11):7-8.

Chattopadhyay, Suchismita. 2015. “An (in)Decent Proposal, The Need to Take the Mediating Character of the Bourgeois Writing Seriously." JNU pamphlet. Indecent Proposal. PaRChA archive ID-72433.

Chaudhry, Apurva. 2017. "2017 JNU Admissions-Over 80\% Seat Cut for Researchers.” Newsclick March 22. Retrieved November 29,2019 (https://www.newsclick.in/2017-jnu-admissions-over-80seat-cut-researchers)

Chaudhuri, Paramita. 2008. "Sexual Harassment at the Workplace: Experiences with Complaints Committees." Economic and Political Weekly 43(17):99-106.

Chauhan, Chandra Pal Singh. 2008. "Education and Caste in India." Asia Pacific Journal of Education 28(3):217-34.

Chitnis, Suma. 1972. "Education for Equality: Case of Scheduled Castes in Higher Education." Economic and Political Weekly 7(31/33):1675-81. 
Chopra, Suneet. 1978. "Political Consciousness of the Student Movement in India." Social Scientist 6(10):53-68.

Christiansen, Samantha. 2012. "Beyond Liberation: Students, Space, and the State in East Pakistan/Bangladesh 1952-1990." PhD dissertation, Department of History, Northeastern University.

Ciotti, Manuela. 2006. “"In the Past We Were a Bit "Chamar”': Education as a Self- and Community Engineering Process in Northern India." Journal of the Royal Anthropological Institute 12(4):899-916.

Cormack, Margaret Lawson. 1961. She Who Rides a Peacock; Indian Students and Social Change. New York: Praeger.

Couto, Richard A. 1993. "Narrative, Free Space, and Political Leadership in Social Movements." The Journal of Politics 55(1):57-79.

Dasgupta, Piyasree. 2018. "In JNU, Several Professors Stand Accused of Plagiarism." The Huffington Post. April 13. Retrieved December 10, 2019 (https://www.huffingtonpost.in/2018/04/13/in-jnuat-least-five-new-appointees-and-two-other-professors-are-being-accused-ofplagiarism_a_23408282/).

Deka, Kaustubh. 2013. From Movements to Accords and Beyond: The Critical Role of Student Organizations in the Formation and Performance of Identity in Assam. New Delhi: Nehru Memorial Museum and Library.

Dennis, Subin. 2014. "The School of Language, Literature and Culture Studies-What We Want from the JNUSU.” JNU pamphlet. PaRChA archive, SFI Unit, ID-68963, ID-68964.

Deshpande, Ashwini and Katherine Newman. 2007. "Where the Path Leads: The Role of Caste in Post-University Employment Expectations.” Economic and Political Weekly 42(41):4133-40.

Deshpande, Satish. 2015. “The Public University after Rohith-Kanhaiya.” Economic and Political Weekly 51(11):7-8.

Devy, G. N. 2017. The Crisis Within: On Knowledge and Education in India. New Delhi: Aleph Book Company.

Dey, Adrija. 2018. Nirbhaya. New Media and Digital Gender Activism. Bingley, United Kingdom: Emerald Publishing Limited.

Dhanak. 2015. "With This Contention, and Expectation for a More Vibrant and Active GSCASH, Dhanak Would like to Put Forward Some Important Demands/Issues." JNU pamphlet. PaRChA ID-67424.

Di Bona, Joseph. 1966. “Indiscipline and Student Leadership in an Indian University.” Comparative Education Review 10(2):306-19.

Duchastel, Jules, Louis-Claude Paquin, and Jacques Beauchemin. 1992. “Automated Syntactic Text Description Enhancement: The Thematic Structure of Discourse Utterances." Computers and the Humanities 26(1):31-42.

Dutoya, Virginie. 2016. “Defining the 'Queers' in India: The Politics of Academic Representation.” India Review 15(2):241-71.

Earl, Jennifer, Thomas V. Maher, and Thomas Elliott. 2017. "Youth, Activism, and Social Movements." Sociology Compass 11(4):124-65.

Enriquez, Laura E. 2014. “'Undocumented and Citizen Students Unite': Building a Cross-Status Coalition through Shared Ideology.” Social Problems 61(2):155-74. 
Evans, Sara M. and Harry C. Boyte. 1992. Free Spaces: The Sources of Democratic Change in America. Chicago: University of Chicago Press.

Fantasia, Rick. 1989. Cultures of Solidarity: Consciousness, Action and Contemporary American Workers. Berkeley: University of California Press.

Fantasia, Rick and Eric Hirsch. [1995] 2003. "Culture in Rebellion: The Appropriation and Transformation of the Veil in the Algerian Revolution." Pp. 144-62 in Social Movements and Culture, edited by H. Johnston and B.Klandermans, Minneapolis: University of Minnesota Press.

Fernandez, Marilyn. 2018. The New Frontier: Merit vs. Caste in the Indian IT Sector. New Delhi: Oxford University Press.

Fillieule, Olivier. 2013. "Political Socialization and Social Movements." Pp. 610-616 in The WileyBlackwell Encyclopedia of Social and Political Movements, edited by D. Snow, D. della Porta, B. Klandermans, and D. McAdam. Oxford, UK: Blackwell Publishing Ltd.

Futrell, Robert and Pete Simi. 2004. "Free Spaces, Collective Identity, and the Persistence of U.S. White Power Activism." Social Problems 51(1):16-42.

Garalytė, Kristina. 2015. “Subaltern Autonomy: Dalit Students' Identity Politics in India." Grupés Ir Aplinkos (4):49-76.

Gautier, Laurence. 2018. "Why Does the UGC Want to Drop the 'M' from AMU?" Economic and Political Weekly 53(1):7-8.

Gender Sensitisation Committee Against Sexual Harassment (GSCASH). 2016. GSCASH Annual Report, 2016. New Delhi: JNU Publication.

Ghosh, Gourab. 2016. "Queer Narratives from JNU.” Café Dissensus. Retrieved October 11, 2019 (https://cafedissensus.com/2016/04/11/queer-narratives-from-jnu/).

Ghosh, Jayati. 2006. "Case for Caste-Based Quotas in Higher Education.” Economic and Political Weekly 41(24):2428-32.

Ghosh, Saikat. 2015. “'Autonomy' for Universities: Government's Move to Privatise is Exclusionary." Economic and Political Weekly 53(13):7-8.

Giugni, Marco. 2013. “Biographical Consequences of Activism.” Pp. 62-67 in The Wiley-Blackwell Encyclopedia of Social and Political Movements, edited by D. Snow, D. della Porta, B. Klandermans, and D. McAdam. Oxford, United Kingdom: Blackwell Publishing Ltd.

Gréa, Philippe. 2017. “Inside in French.” Cognitive Linguistics 28(1):77-130.

Gundimeda, Sambaiah. 2009. "Democratisation of the Public Sphere: The Beef Stall Case in Hyderabad's Sukoon Festival." South Asia Research 29(2):127-49.

Gusfield, Joseph R. 1970. Protest, Reform, and Revolt: A Reader in Social Movements. New York: Wiley. Haverland, Markus and Dvora Yanow. 2012. "A Hitchhiker's Guide to the Public Administration Research Universe: Surviving Conversations on Methodologies and Methods." Public Administration Review 72(3):401-8

Hazary, Subas Chandra. 1987. Student Politics in India. New Delhi: Ashish Publishing House.

Heiden, Serge, Mathieu Decorde, and Benedicte Pincemin. 2018. Manuel de TXM. Lyon: ENS

Henry, Nikhila. 2018. The Ferment: Youth Unrest in India. New Delhi: Palgrave Macmillan India. 
Henry, Odile and Mathieu Ferry. 2017. "When Cracking the JEE Is Not Enough. Processes of Elimination and Differentiation, from Entry to Placement, in the Indian Institutes of Technology (IITs)." South Asia Multidisciplinary Academic Journal (15).

Hirsch, Eric L. 1990. Urban Revolt: Ethnic Politics in the Nineteenth-Century Chicago Labor Movement. Berkeley: University of California Press.

Hirslund, Dan Vesalainen. 2012. "Sacrificing Youth: Maoist Cadres and Political Activism in PostWar Nepal.” PhD dissertation. Faculty of Social Sciences, University of Copenhagen.

Imran, Mohammad. 2018. "Why Jai Bhim-Jai Pasmanda Rather than Jai Bhim-Jai Meem.” Round Table India. Retrieved October 11, 2019 (http://roundtableindia.co.in/index.php? option=com_content\&view=article\&id=9480:why-jai-bhim-jai-pasmanda-rather-than-jai-bhimjai-meem\&catid=119:feature\&Itemid=132).

Jackman, David. 2018. "Violent Intermediaries and Political Order in Bangladesh." The European Journal of Development Research 31(4):705-723.

Jaffelot, Christophe. 2007. Hindu Nationalism-A Reader. Princeton, NJ: Princeton University Press. Jayal, Niraja Gopal. 2019. "Fear and Desire: Crippling the Public University.” Pp. 359-70 in Reforming India: The Nation Today, edited by N. Jayal. Gurgaon: Penguin/Viking.

Jawaharlal Nehru University Teachers' Association. 2017. "JNUTA Protests the Supersession of 5 Senior Professors in Appointment of Dean SSS." October 1. Retrieved October 10, 2019 (https:// jnuta.wordpress.com/2017/10/01/3031/).

Jawaharlal Nehru University Teachers Association. 2017. "JNUTA Statement on the Removal of Prof. Nivedita Menon as Chairperson of CCPT/SIS.” Retrieved March 5, 2019 (https:// jnuta.wordpress.com/2017/09/19/jnuta-statement-on-the-removal-of-prof-nivedita-menon-aschairperson-of-ccptsis/).

Jeffrey, Craig. 2008. "Kicking Away the Ladder: Student Politics and the Making of an Indian Middle Class." Environment and Planning D: Society and Space 26(3):517-36.

Jeffrey, Craig. 2010. Timepass: Youth, Class, and the Politics of Waiting in India. Stanford, CA: Stanford University Press.

Jeffrey, Craig, Patricia Jeffery, and Roger Jeffery. 2008. Degrees without Freedom? Education, Masculinities, and Unemployment in North India. Stanford, CA: Stanford University Press.

Jeffrey, Craig and Stephen Young. 2012. "Waiting for Change: Youth, Caste and Politics in India." Economy and Society 41(4):638-61.

Jeffrey, Craig and Stephen Young. 2014. "Jugād: Youth and Enterprise in India." Annals of the Association of American Geographers 104(1):182-95.

Jeffrey, Craig and Jane Dyson. 2016. "Now: Prefigurative Politics through a North Indian Lens." Economy and Society 45(1):77-100.

John, Vincent. 1969. “Student Unrest in India." Quest 61(1).

Johnston, Hank. 1991. Tales of Nationalism: Catalonia, 1939-1979. New Brunswick, NJ: Rutgers University.

Johnston, Hank and John A. Noakes. 2005. Frames of Protest: Social Movements and the Framing Perspective. Lanham, MD: Rowman and Littlefield Publishers.

Kabir, Humayun. 1958. Student Unrest: Causes and Cure. New Delhi: Orient Book Company. 
Kapur, Devesh and Pratap Bhanu Mehta, eds. 2017. Navigating the Labyrinth: Perspectives on India's Higher Education. Hyderabad: Orient BlackSwan.

Karnena, Ravindra. 2019. “A Mirror and a Crucible: Observations on Student Politics in Our Times.” Pp. 343-58 in Re-forming India: The Nation Today, edited by N. G. Jayal. Gurgaon: Penguin/ Viking.

Kidwai, Ayesha. 2015. "UGC and JNU: A Tale of Exception Told in Two Acts." Economic and Political Weekly 52(16).

Kidwai, Ayesha. 2018. “The Many Reasons Behind the Anger in JNU.” The Wire. March 6. Retrieved March 8, 2019 (https://thewire.in/education/jnu-hiring-attendance-students-admission).

Kirpal, Viney, Nalini Swamidasan, Amitabha Gupta, and Raj K. Gupta. 1985. "Scheduled Caste and Tribe Students in Higher Education: A Study of an IIT." Economic and Political Weekly 20(29):123848.

Klandermans, Bert. 1997. The Social Psychology of Protest. Oxford, UK; Cambridge, MA: Blackwell Publishers.

Klemenčič, Manja. 2015. “Student Involvement in University Quality Enhancement.” Pp. 526-43 in The Palgrave International Handbook of Higher Education Policy and Governance, edited by J. Huisman, H. de Boer, D. D. Dill, and M. Souto-Otero. London: Palgrave Macmillan UK.

Kumar, Amit. 2018. "From Stigma to Assertion: BAPSA in JNU Campus.” Round Table India. Retrieved October 11, 2019 (http://roundtableindia.co.in/index.php? option=com_content\&view=article\&id=9350\%3Afrom-the-politics-ofstigma\&catid $=119 \% 3$ Afeature\&Itemid=132).

Kumar, Jagadesh. 2017. JNU Academic Rules and Regulations. Executive Council. Delhi: Jawaharlal Nehru University. Administrative Document.

Kumar, Sanjay. 2014. Indian Youth and Electoral Politics: An Emerging Engagement. New Delhi: SAGE Publications India.

Kumar, Sanjay. 2017. Attitudes, Anxieties and Aspirations of India's Youth. Centre for the Study of Developing Societies. CSDS- KAS Report.

Kumar, Satendra. 2012. "Ethnography of Youth Politics: Leaders, Brokers and Morality in a Provincial University in Western Uttar Pradesh." History and Sociology of South Asia 6(1):41-70.

Kumar, Satendra. 2014. "Privatisation of Higher Education in India: Hopes and Despairs." Social Change 44(3):451-58.

Kumar, Satendra. 2018. Badalte gaon, badalta dehat: nayi samajikta ka uday. New Delhi: OUP India. Leach, Darcy K. and Sebastian Haunss. 2008. "Scenes and Social Movements.” Pp. 255-76 in Culture, Social Movements, and Protest, edited by H. Johnston. Farnham, UK: Ashgate Publishing. Léon, Jacqueline and Sylvain Loiseau, eds. 2016. History of Quantitative Linguistics in France. Lüdenscheid: RAM-Verlag.

Lochan, Kanchan. 1996. JNU, The Years: An Anthology by the Silver Memoir Committee. Mumbai: Popular Prakashan.

Lukose, Ritty A. 2009. Liberalization's Children: Gender, Youth, and Consumer Citizenship in Globalizing India. Durham: Duke University Press. 
Mahaprashasta, Ajoy Ashirwad. 2018. "Allegations of Political Bias in Faculty Hiring the Latest Battleline in JNU.” The Wire. January 25. Retrieved December 10, 2019 (https://thewire.in/ education/allegations-political-bias-faculty-hiring-latest-battleline-jnu).

Malik, Yogendra K. and Jesse F. Marquette. 1974. "Changing Social Values of College Students in the Punjab." Asian Survey 14(9):795-806.

Groch, Sharon. 2001. "Free Spaces: Creating Oppositional Consciousness in the Disability Rights Movement." in Oppositional Consciousness: The Subjective Roots of Social Protest, edited by J. Mansbridge and A. Morris. Chicago: University of Chicago Press.

Martelli, Jean-Thomas. 2017. “Waiting for the Liberal Indian Enfant Terrible.” Asia Dialogue. July 14. Retrieved March 8, 2019 (http://theasiadialogue.com/2017/07/14/waiting-for-the-liberalenfant-terrible/).

Martelli, Jean-Thomas. 2018. “'JNU Is Not Just Where You Go, It's What You Become' Everyday Political Socialisation and Left Activism at Jawaharlal Nehru University (JNU), New Delhi.” PhD dissertation, Political Science and Sociology. King's India Institute, King's College London.

Martelli, Jean-Thomas and Barış Arı. 2018. "From One Participant Cohort to Another: Surveying Inter-Generational Political Incubation in an Indian University." India Review 17(3):263-300.

Martelli, Jean-Thomas and Khaliq Parkar. 2018. "Diversity, Democracy, and Dissent: A Study on Student Politics in JNU." Economic and Political Weekly 53(11):3597-606.

Martelli, Jean-Thomas. 2019. "The Politics of Our Selves: Left Self-fashioning and the Production of Representative Claims in Everyday Indian Campus Politics.” Modern Asian Studies. Revise and resubmit, R3.

Mayaffre, Damon. 2014. "Plaidoyer en Faveur de l'analyse de Données Co(n)textuelles. Pp. 15-32 in Parcours Cooccurrentiels dans le Discours Présidentiel Français (1958-2014).” Nice: HAL.

Mayaffre, Damon. 2016. “Méthodes et Outils Statistiques en Analyse des Données Textuelles." Besançon: École thématique du MISAT.

McAdam, Doug. 1986. "Recruitment to High-Risk Activism: The Case of Freedom Summer." American Journal of Sociology 92(1):64-90.

McAdam, Doug. 1990. Freedom Summer. Oxford, NY: Oxford University Press.

McAdam, Doug. 1995. "Initiator and Spin off Movements: Diffusion Processes in Protest Cycles." in Repertoires and Cycles of Collective Action, edited by M. Traugott. Durham: Duke University Press.

McAdam, Doug. 2013. “Initiator and Spin-Off Movements.” Pp. 316-in The Wiley-Blackwell Encyclopedia of Social and Political Movements, edited by D. A. Snow, D. della Porta, B. Klandermans, and D. McAdam. Oxford, UK: Blackwell Publishing Ltd.

McCallum, Andrew. 2002. MALLET: A Machine Learning for Language Toolkit. Amherst: University of Massachusetts. Retrieved December 5, 2019 (http://mallet.cs.umass.edu/).

McKee, Alan. 2003. Textual Analysis: A Beginner's Guide. London; Thousand Oaks, CA: Sage Publications.

Melucci, Alberto. 1985. "The Symbolic Challenge of Contemporary Movements." Social Research 52(4):789-816.

Melucci, Alberto. 1996. "Youth, Time and Social Movements." YOUNG 4(2):3-14.

Meyer, David S. and Nancy Whittier. 1994. "Social Movement Spillover." Social Problems 41(2):27798. 
Mitchell, Paul, Geoffrey Evans, and Brendan O'Leary. 2009. “Extremist Outbidding in Ethnic Party Systems Is Not Inevitable: Tribune Parties in Northern Ireland.” Political Studies 57(2):397-421.

Mitra, Subrata K. 2017. “Civil Society and Its Shadow.” Journal of Democracy 28(3):106-16.

Morris, Aldon D. 1986. The Origins of the Civil Rights Movement. New York: Simon and Schuster.

Taylor, Verta and Nancy Whittier. 1992. "Collective Identity in Social Movement Communities: Lesbian Feminist Mobilization." Pp. 104-29 in Frontiers in Social Movement Theory, edited by A. Morris and C. Mueller. New Haven, CT: Yale University Press.

Mueller, Carol. 1994. “Conflict Networks and the Origins of Women's Liberation.” Pp. 234-63 in New Social Movements: From Ideology to Identity, edited by E. Larana, J. Gusfield, and H. Johnston. Philadelphia: Temple University Press.

Nagarajan, Kedar. 2017. "How JNU Flouted Procedure to Revise Admission Criteria, Ignoring and Aggravating Concerns of Caste Discrimination.” The Caravan. January 29. Retrieved December 10, 2019 (https://caravanmagazine.in/vantage/jnu-admission-caste-discrimination).

Nambissan, Geetha B. and S. Srinivasa Rao, eds. 2013. Sociology of Education in India: Changing Contours and Emerging Concerns. New Delhi: Oxford University Press.

Natrajan, Balmurli. 2011. The Culturalization of Caste in India: Identity and Inequality in a Multicultural Age. New Delhi: Routledge.

Natrajan, Balmurli. 2018. "Cultural Identity and Beef Festivals: Toward a 'Multiculturalism Against Caste." Contemporary South Asia 26(3):287-304.

Nelson, Matthew J. 2011. “'Faith' and 'Development' in Secular and Religious Schools.” Comparative Education Review 55:115-17, 129.

India.com. 2016. "JNU Students Union Elections 2016: AISA, SFI Form Alliance against ABVP; Everything You Need to Know About Left vs Right Fight." September 7. Retrieved November 29, 2019 (https://www.india.com/news/india/jnu-students-union-elections-2016-aisa-sfi-formalliance-against-abvp-everything-you-need-to-know-about-left-vs-right-fight-1465350/)

Nisbett, Nicholas. 2007. "Friendship, Consumption, Morality: Practising Identity, Negotiating Hierarchy in Middle-Class Bangalore." Journal of the Royal Anthropological Institute 13(4):935-50.

Nnawulezi, Nkiru A. and Cris M. Sullivan. 2014. “Oppression Within Safe Spaces: Exploring Racial Microaggressions within Domestic Violence Shelters.” Journal of Black Psychology 40(6):563-91.

Osella, Caroline and Filippo Osella. 1998. "Friendship and Flirting: Micro-Politics in Kerala, South India." The Journal of the Royal Anthropological Institute 4(2):189-206.

Pai, Sudha. 2018. "Dalit Question and Communalism in Uttar Pradesh in the 2000s." Social Change 48(4):645-52.

Pallikonda, Manikanta. 2018. "BAPSA: A Challenge to the ABVP and Pseudo-Left in JNU." Roundtable India. Retrieved October 11, 2019 (http://roundtableindia.co.in/index.php? option=com_content\&view=article\&id=9454:bapsa-a-challenge-to-the-abvp-and-pseudo-left-injnu\&catid=129:events-and-activism\&Itemid=195).

Paranjape, Madhu. 2015. “Deepening Crisis of Governance in University of Mumbai." Economic and Political Weekly 52(41):7-8.

PaRChA Student Archive (1970-Now) 2019. "Parcha Project The Pamphlet Repository for Changing Activism.” Retrieved October 11, 2019 (https://www.flickr.com/photos/ parchaproject/). 
Pathania, Gaurav. 2018. The University as a Site of Resistance: Identity and Student Politics. Oxford; New Delhi: Oxford University Press.

Pattnaik, Surendra Kumar. 1982. Student Politics and Voting Behaviour: A Case Study of Jawaharlal Nehru University. New Delhi: Concept.

Pettigrew, Judith and Sara Shneiderman. 2004. "Women and the Maobadi: Ideology and Agency in Nepal's Maoist Movement.” Himal Southasian 7(1):19-29.

Pincemin, Bénédicte. 2018. “Sept Logiciels de Textométrie.” Lyon: IHRIM Publication.

Polletta, Francesca. 1999. “'Free Spaces' in Collective Action.” Theory and Society 28(1):1-38.

Polletta, Francesca. 2014. “Participatory Democracy's Moment.” Journal of International Affairs 68(1):79-92.

Poonam, Snigdha. 2018. Dreamers: How Young Indians Are Changing the World. London: Hurst.

Prabodh, Chandra. n.d. Student Movement in India. Lahore: All-India Students' Federation Publication Depot.

Press Trust of India. 2018. “AISA-SFI-DSF-AISF Alliance, ABVP and NSUI Announce Candidates for JNUSU Polls.” Business Standard. July 5. Retrieved December 12, 2019 (https://www.businessstandard.com/article/pti-stories/aisa-sfi-dsf-aisf-alliance-abvp-and-nsui-announce-candidatesfor-jnusu-polls-118090501300_1.html)

Press Trust of India. 2019. "Delhi High Court Sets Aside JNU Appointment Order of Linguistic Centre Chairperson.” NDTV Education, August 30. Retrieved November 10, 2019 (https:// www.ndtv.com/education/delhi-high-court-sets-aside-jnu-appointment-order-of-linguisticcentre-chairperson-2077725).

Press Trust of India. 2019. "JNUSU Elections 2019: High Court Stays Result Notification till September 17." Hindustan Times. September 7. Retrieved December 12, 2019 (https:// www.hindustantimes.com/education/jnusu-elections-2019-high-court-stays-result-notificationtill-september-17/story-8gnwPFwe3uugM97Y83unSo.html)

Rabushka, Alvin and Kenneth A. Shepsle. 1972. Politics in Plural Societies: A Theory of Democratic Instability. New York: Macmillan Publishing Company, Incorporated.

Rajimwale, Anil. 2001. History of Student Movement in India: Origins and Development (1920-1947). New Delhi: Manak Publications.

Reddy, Muni. 1947. The Student Movement in India. Hyderabad: K.S.R. Acharya.

Rege, M. P. 1970. “Inter-Generational Conflict: A Theoretical Perspective.” Pp. 29-56 in Intergenerational Conflict in India. New Delhi: Nachiket Publication.

Roggeband, Conny. 2004. “'Immediately I Thought We Should Do the Same Thing': International Inspiration and Exchange in Feminist Action against Sexual Violence." European Journal of Women's Studies 11(2):159-75.

Rogers, Everett M. [1962]1995. Diffusion of Innovations. New York: Free Press.

Ross, Aileen D. 1969. Student Unrest in India: A Comparative Approach. Montreal: McGill-Queen's University Press.

Roy, Srila. 2016. "Breaking the Cage.” Dissent Magazine. Retrieved March 1, 2019 (https:// www.dissentmagazine.org/article/breaking-cage-india-feminism-sexual-violence-public-space). 
Rozario, Santi. 2001. "Claiming the Campus for Female Students in Bangladesh.” Women's Studies International Forum 24(2):157-66.

Rudolph, Lloyd I. and Susanne Hoeber Rudolph. 1987. In Pursuit of Lakshmi: The Political Economy of the Indian State. Chicago: University of Chicago Press.

Rupp, Leila J. and Verta A. Taylor. 1987. Survival in the Doldrums: The American Women's Rights Movement, 1945 to the 1960s. New York: Oxford University Press.

Ruud, Arild Engelsen. 2014. “The Political Bully in Bangladesh.” Pp. 303-25 in Patronage as Politics in South Asia, edited by A. Piliavsky. Cambridge: Cambridge University Press.

Ruud, Arlid. 2012. “To Create a Crowd: Student Leaders in Dhaka." Pp. 70-95 in Power and Influence in India: Bosses, Lords and Captains (Exploring the Political in South Asia), edited by P. Price and A. E. Ruud. Hoboken: Taylor and Francis.

Sarkar, Aranya. 2018. "Faculty Selection in JNU: Cracks on Campus." The Indian Express, June 25. Retrieved on December 12, 2019 (https://indianexpress.com/article/education/faculty-selectionin-jnu-cracks-on-campus-5042818/)

Savory Fuller, Rebecca. 2018. “Embodying ‘New India' through Remixed Global Performance: Flash Mobs Redefined in Contemporary Urban India." PhD dissertation, Drama Department, University of Exeter.

Scott, James C. 1990. Domination and the Arts of Resistance: Hidden Transcripts. New Haven: Yale University Press.

Scroll. 2018. "JNU Teachers' Association to Begin Hunger Strike Against Removal of Faculty Members.” Retrieved March 5, 2019 (https://scroll.in/latest/872316/jnu-teachers-association-tobegin-hunger-strike-against-removal-of-faculty-members).

Shah, Ghanshyam. 2004. "Students' Movements." in Social Movements in India: A Review of Literature. New Delhi: Sage Publications.

Shakil, Albeena. n.d. "JNUSU: 2001-02." in 30 Years in Defence of Progressive Democratic and Secular Culture. JNUSU office bearers' document.

Shankar, Aranya. 2017. "UGC Tightens Purse Strings, JNU V-C Says Research Will Suffer.” The Indian Express, March 3. Retrieved on November 10, 2019 (https://indianexpress.com/article/ education/ugc-tightens-purse-strings-jnu-v-c-says-research-will-suffer-4638104/).

Sharma, K. L. 2015. “Why India Needs JNU.” Economic and Political Weekly 51(23):7-8.

Shils, Edward. 1961. Indian Students: Rather Sadhus than Philistines. Chicago: University of Chicago.

Shobhana, Nidhin. 2018. "Challenging Heterogeneity in Universities." Round Table India.

Retrieved November 10, 2019 (https://roundtableindia.co.in/index.php?

option=com_content\&view=article\&id=8481:challenging-heterogeneity-inuniversities\&catid=119:feature\&Itemid=132).

Singh, Pratap. 1974. “Leadership.” Seminar 176:152-173.

Singh, A. K. 1968. "Academic Politics and Student Unrest: The Case of Ranchi University." in The Student Revolution: A Global Analysis. New Delhi: Lalvani.

Singh, Sandeep. 2007a. "Violence during the proceedings of the JNUSU presidential debate (1)." Letter to presidential candidates. November 6. PaRChA archive ID-66343.

Singh, Sandeep. 2007b. "Violence during the proceedings of the JNUSU presidential debate (2)." Letter to the rector. November 21. PaRChA archive ID-66329. 
Singh, Soibam Rocky. 2019. “JNU Faculty Selection Panel Told to Get Academic, Executive Bodies' Nod." The Hindu. May 17. Retrieved on November 10, 2019 (https://www.thehindu.com/news/ cities/Delhi/jnu-faculty-selection-panel-told-to-get-academic-executive-bodies-nod/ article27154516.ece).

Singhvi, Laxmi M. 1972. Youth Unrest: Conflict of Generations. Delhi: National.

Sinha, M. P., K. D. Gangrade, eds. 1971. “Inter-generational Conflict in India.” Seminar on InterGenerational Conflict in India. Bombay: Nachiketa Publications.

Snellinger, Amanda. 2005. "A Crisis in Nepali Student Politics? Analyzing the Gap between Politically Active and Non-Active Students.” Peace and Democracy in South Asia 2(1):18-44.

Snellinger, Amanda. 2010. "Transfiguration of The Political: Nepali Student Activism And The Politics Of Acculturation." PhD dissertation, Department of Philosophy, Cornell University.

Snellinger, Amanda. 2012. "The Young Political Generation Today, Five Years Later." Himalaya, the Journal of the Association for Nepal and Himalayan Studies 31(1): Article 15.

Snellinger, Amanda. 2013. "Shaping a Livable Present and Future: A Review of Youth Studies in Nepal.” European Bulletin of Himalayan Research 42(1):75-103.

Snellinger, Amanda. 2018. "From (Violent) Protest to Policy: Rearticulating Authority through the National Youth Policy in Post-War Nepal." Modern Asian Studies 52(03):1043-75.

Snellinger, Amanda. 2018. Making New Nepal: From Student Activism to Mainstream Politics. Seattle: University of Washington Press.

Subramanian, Ajantha. 2015. "Making Merit: The Indian Institutes of Technology and the Social Life of Caste." Comparative Studies in Society and History 57(02):291-322.

Subramanian, Narendra. 2001. Ethnicity and Populist Mobilization: Political Parties, Citizens and Democracy in South India. New Delhi: Oxford University Press.

Sundar, Nandini. 2015. “Academic Freedom and Indian Universities." Economic and Political Weekly 53(24):7-8.

Sundaram, Krishnamurthy. 2006. "On Backwardness and Fair Access to Higher Education: Results from NSS 55th Round Surveys, 1999-2000.” Economic and Political Weekly 41(50):5173-82.

Suroor, Hasan. 2011. "The Kremlin on the Jumna." The Hindu, April 21. Retrieved on December 10, 2019 (https://www.thehindu.com/news/the-india-cables/lsquoThe-Kremlin-on-the-Jumna/ article14691414.ece)

Suykens, Bert. 2017a. "Segmentary Opposition, Vertical Integration and the Structure of Political Relations in Bangladesh: A Descriptive Model." Journal of Asian and African Studies 52(8):1141-58.

Suykens, Bert. 2017b. "The Bangladesh Party-State: A Diachronic Comparative Analysis of PartyPolitical Regimes.” Commonwealth \& Comparative Politics 55(2):187-213.

Suykens, Bert. 2018. “'A Hundred Per Cent Good Man Cannot Do Politics': Violent Self-Sacrifice, Student Authority, and Party-State Integration in Bangladesh." Modern Asian Studies 52(03):883916.

Suykens, Bert and Aynul Islam. 2013. "Hartal as a Complex Political Performance: General Strikes and the Organization of (Local) Power in Bangladesh." Contributions to Indian Sociology 47(1):61-83. Tarrow, Sidney G. [1994]1998. Power in Movement: Social Movements and Contentious Politics. Cambridge, UK; New York: Cambridge University Press. 
Taylor, Verta. 1989. “Social Movement Continuity: The Women's Movement in Abeyance." American Sociological Review 54(5):761-75.

Taylor, Verta and Alison Dahl Crossley. 2013. “Abeyance.” Pp. 27-8 in The Wiley-Blackwell Encyclopedia of Social and Political Movements, edited by D. A. Snow, D. della Porta, B. Klandermans, and D. McAdam. Oxford, UK: Blackwell Publishing Ltd.

Taylor, Verta and Leila J. Rupp. 1993. “Women's Culture and Lesbian Feminist Activism: A Reconsideration of Cultural Feminism.” Signs: Journal of Women in Culture and Society 19(1):32-61.

Taylor, Verta and Nancy Whittier. 1995. “Analytical Approaches to Social Movement Culture: The Culture of the Women's Movement.” Pp. 163-88 in Social Movements and Culture, Volume 4. Minneapolis: University of Minnesota Press.

Teltumbde, Anand. 2015. “Azadi Kooch: Towards a New Grammar of the Dalit Struggle.” Economic and Political Weekly 52(31):7-8.

Thapan, Meenakshi, ed. 2015. Education and Society: Themes, Perspectives, Practices. New Delhi: Oxford University Press.

Thapar, Romila. 2015. "Targeting Institutions of Higher Education." Economic and Political Weekly 51(10):7-8.

The Indian Express. 2018. “JNUSU Seeks Lok Sabha Help over 'Reservation Violation.” April 5. Retrieved December 12, 2019 (https://indianexpress.com/article/cities/delhi/jnusu-seeks-loksabha-help-over-reservation-violation-5123729/)

Tilak, Jandhyala B. G., ed. 2013. Higher Education in India: In Search of Equality, Quality and Quantity. New Delhi: Orient Blackswan.

Tilly, Charles. 1983. "Speaking Your Mind Without Elections, Surveys, or Social Movements." The Public Opinion Quarterly 47(4):461-78.

van Dyke, Nella. 1998. "Hotbeds of Activism: Locations of Student Protest." Social Problems 45(2): 205-20.

van Stekelenburg, Jacquelien. 2013. "Political Socialization and Social Movements." Pp. 610-16 in The Wiley-Blackwell Encyclopedia of Social and Political Movements, edited by D. A. Snow, D. della Porta, B. Klandermans, and D. McAdam. Oxford, UK: Blackwell Publishing Ltd.

Vidyarthi, Lalita Prasad. 1976. Students Unrest in Chotanagpur, 1969-70. Ranchi: Punthi Pustak.

Vishnu, Uma. 2017. "New Faultlines in JNU after Deep Cuts in Research Seats." The Indian Express, April 11. Retrieved on December 10, 2019 (https://indianexpress.com/article/india/newfaultlines-in-jnu-after-deep-cuts-in-research-seats-4608207/)

Visvanathan, Shiv. 2000. "Democracy, Plurality and Indian University." Economic and Political Weekly 35(40):3597-606.

Weisskopf, Thomas. 2004. "Impact of Reservation on Admissions to Higher Education in India." Economic and Political Weekly 39(39):4339-49.

Whittier, Nancy. 1997. "Political Generations, Micro-Cohorts, and the Transformation of Social Movements.” American Sociological Review 62(5):760.

Whittier, Nancy. 2013. "Spillover, Social Movement." Pp. 619-20 in The Wiley-Blackwell Encyclopedia of Social and Political Movements, edited by D. A. Snow, D. della Porta, B. Klandermans, and D. McAdam. Oxford, UK: Blackwell Publishing Ltd. 
Wong, Janelle and Vivian Tseng. 2008. "Political Socialisation in Immigrant Families: Challenging Top-Down Parental Socialisation Models." Journal of Ethnic and Migration Studies 34(1):151-68.

Young, Stephen, Satendra Kumar, and Craig Jeffrey. 2016. "Beyond Improvisation? The Rise and Rise of Youth Entrepreneurs in North India." Transactions of the Institute of British Geographers 42(1):98-109.

Zhao, Dingxin. 1998. "Ecologies of Social Movements: Student Mobilization during the 1989 Prodemocracy Movement in Beijing.” American Journal of Sociology 103(6):1493-529.

Zharkevich, Ina. 2009. "A New Way of Being Young in Nepal: The Idea of Maoist Youth and Dreams of a New Man." Studies in Nepali History and Society 14(1):67-105.

Zharkevich, Ina. 2013. "Learning in a Guerrilla Community of Practice: Literacy Practices, Situated Learning and Youth in Nepal's Maoist Movement (1996-2006)." European Bulletin of Himalayan Research 42(1):104-32.

\section{NOTES}

1. I gratefully acknowledge financial support from the French Agence Nationale de la Recherche through the research project Challenging Inequalities: An Indo-European perspective (ANR-18EQUI-0003)

2. For further reading, cf. Chitnis 1972; Kirpal et al. 1985; Visvanathan 2000; Weisskopf 2004; Deshpande 2006; Sundaram 2006; Ghosh 2006; Ciotti 2006; Deshpande and Newman 2007; Chauhan 2008; Sen and Basant 2010; Nambissan and Rao 2013; Thapan 2014; Tilak 2015; Subramanian 2015; Henri and Ferry 2017; Chandra 2017; Devy 2017; Kapur and Mehta 2017; Kumar 2018; Fernandez 2018.

3. See for instance Pettigrew and Shneiderman 2004; Zharkevich 2009 and 2013; Snellinger 2005, 2010, 2012, 2013 and 2018b; Hirslund 2012.

4. According to the 2014-2015 attitude survey (Martelli and Parkar 2018), more than four-fifths of JNU students live in on-campus residences (0.81). On average, they join the university at the age of 22 years old $(22.29 ; \mathrm{SD}=3.14 ; \mathrm{N}=365)$. The mean study duration for post graduates is around five semesters ( $4.95 ; \mathrm{SD}=3.22 ; \mathrm{N}=612$ ).

5. The GSCASH was set up at JNU in 1999 applying the guidelines set by the Indian Supreme Court in 1997 (Chaudhuri 2007). Its missions are formal enquiry and redressal of cases of sexual harassment on campus, assistance and mediation of complaints and the sensitization of students on gender issues through the organization of programs and workshops (GSCASH Annual Report 2016).

6. For this analysis, I used Mallet, a topic modelling tool (McCallum 2002). A "topic" consists of a cluster of words that frequently occur together.

\section{ABSTRACTS}

The recent spur of student-led mobilizations in India led to the portrayal of select public universities as the epitome of resistance, dissent and countercultural politics. Departing from essentialist approaches to student politics, this article outlines the processes by which campus 
spaces activate the formation of political attitudes among participants. It builds on an archival and ethnographic account of educated youth politics in one of the most politicized universities in the country, Jawaharlal Nehru University. I suggest that everyday political competition among student organizations is a central condition for the development of dissonant political participation, as it enables both inter-cohort political socialization and the spilling over of ideological idioms to the sociologically diverse student groups on campus. I argue that mechanisms of political outbidding sustained by politically enterprising student collectives nurture value-based dissent by continually emulating political counter-narratives while fostering ideational cross-fertilization.

INDEX

Keywords: student politics, spillover, diffusion, spinoffs, political socialization, campus, dissent, dissonance, free space, ideology, JNU

\section{AUTHOR}

\section{JEAN-THOMAS MARTELLI}

Centre de Sciences Humaines (CSH), Politics and Society Division, New Delhi 